\title{
Chronostratigraphy and environment of Furnas Formation by trace fossil analysis: Calibrating the lower Paleozoic Gondwana realm in the Paraná Basin (Brazil)
}

\author{
Daniel Sedorko $^{\mathrm{a}, *}$, Renata G. Netto ${ }^{\mathrm{a}}$, Charles E. Savrda ${ }^{\mathrm{b}}$, Mario L. Assine ${ }^{\mathrm{c}}$, \\ Francisco M.W. Tognoli ${ }^{\mathrm{a}}$
}

a Unisinos University, Geology Graduate Program, Av. Unisinos, 950, Cristo Rei, São Leopoldo, RS 93022750, Brazil

b Auburn University, Department of Geosciences, 2050 Beard-Eaves Memorial Coliseum, Auburn, AL 36849, USA

${ }^{c}$ Universidade Estadual Paulista-UNESP/IGCE, Av. 24-A, 1515, 13506-900 Rio Claro, SP, Brazil

\section{A R T I C L E I N F O}

\section{Keywords:}

Silurian

Devonian

Ichnostratigraphy

Skolithos ichnofacies

Cruziana ichnofacies

\begin{abstract}
A B S T R A C T
Ichnology is an important tool for facies and sequence stratigraphic analysis, typically yielding greater resolution than that provided by body fossils. Less commonly, ichnofossils also can be applied to ichnostratigraphy, a variant of biostratigraphy that aids in determining stratigraphic age of sedimentary sequences. Previous publications on the Furnas Formation (Paraná Group, early Paleozoic of the Paraná Basin), have yielded different interpretations of age, depositional environment, and sequence stratigraphic framework. Deposition in fluvial environments has been proposed in many papers, although a tide-influenced marine context has been inferred since the presence of Cruziana and Rusophycus was reported during the 1990s. Sequence stratigraphic interpretations also differ, mainly regarding the presence or absence of a sequence boundary between the middle and upper units of the Furnas Formation. The absence of body fossils in all but the topmost part of the upper unit, which contains Lochkovian (Lower Devonian) palynomorphs and primitive plants, has precluded age determination for the Furnas Formation in general. Here, we demonstrate the utility of both ichnofacies and ichnostratigraphic analysis to elucidate such questions. The studied sections are located in the cities of Tibagi, Palmeira and Ponta Grossa (Guartelá, Sítio Canei and São Jorge sections, respectively). Seventeen ichnotaxa are recognized, doubling the number of previously known ichnotaxa: Cruziana acacensis elongata and Rusophycus acacensis n. ichnosp. (in the lower and middle units); Arthrophycus alleghaniensis, A. brongniartii, Rhizocorallium commune, Didymaulyponomos rowei and Heimdallia chatwini (middle unit only); Arenicolites, Cylindrichnus and Diplocraterion (lower and upper units); Lockeia siliquaria and Psammichnites implexus (middle and upper units); Rosselia socialis (upper unit); and Palaeophycus tubularis, Didymaulichnus lyelli, Skolithos, and Thalassinoides (all units). Assemblages of these ichnofossils are assigned to Skolithos and proximal Cruziana ichnofacies. Ichnologic data, combined with associated physical sedimentary facies associations, indicate predominantly tide-influenced marine depositional environments. The presence of ichnotaxa of stratigraphic value (Arthrophycus alleghaniensis, A. brongniartii and Cruziana acacensis elongata) in lower and middle units indicates an Early Silurian age. This, in turn, indicates that a significant unconformity exists between the middle and upper units of Furnas Formation. Although the precise magnitude of this stratigraphic gap is difficult to establish, this break likely is linked to the Late Silurian global regression.
\end{abstract}

\section{Introduction}

Ichnology has a broad range of applications in sedimentary geology. Ichnofossils reflect aspects of organism behavior that are responses to physical and chemical conditions in their respective depositional environments. Hence, in conjunction with physical sedimentologic evidence, ichnofossils are important tools for facies analysis (Pemberton and Frey, 1984; Bottjer et al., 1988; Savrda and Bottjer, 1986; Ekdale and Lewis, 1991; Leszczyński et al., 1996; Mángano et al., 1998; Netto et al., 2009, 2014; Srivastava and Mankar, 2012; Mude et al., 2012; Plotnick, 2012), typically yielding greater resolution than that provided by body fossils, including palynofossils and foraminifera (MacEachern et al., 1999).

Ichnofossils are also applied effectively in sequence stratigraphic

\footnotetext{
* Corresponding author.

E-mail address: sedorko@edu.unisinos.br (D. Sedorko).
} 
analyses. Key sequence stratigraphic surfaces (e.g., sequence boundaries, transgressive surfaces) are frequently marked by substrate-controlled ichnofossil assemblages (e.g., Glossifungites Ichnofacies; Savrda, 1991a; MacEachern et al., 1992; Pemberton et al., 2000; Buatois and Encinas, 2006; Rodríguez-Tovar et al., 2006; Abdel-Fattah et al., 2016), and vertical changes in ichnofossil assemblages can be used to recognize the signal of sea-level change (e.g., shallowing-upward patterns manifested in parasequences; Savrda, 1991b, 1995; Brett, 1998; Fielding et al., 2006; Rodríguez-Tovar et al., 2010; Paranjape et al., 2014).

Less commonly appreciated among sedimentary geologists, except perhaps those working mainly in the Paleozoic, is the potential use of trace fossils in ichnostratigraphy, a variant of biostratigraphy that aids in determining stratigraphic age of sedimentary sequences (Crimes, 1969, 1970, 1975; Seilacher, 1970, 1992, 1994, 1996, 2000, 2007; Rindsberg and Martin, 2003; Baldwin and Strother, 2004; Mángano et al., 2001; Mángano and Buatois, 2003; Mángano and Droser, 2004; Mángano et al., 2005; Brandt et al., 2010).

The lower Paleozoic siliciclastic Furnas Formation of the Paraná Group in the Paraná Basin of southern Brazil, has been the subject of numerous publications that have yielded conflicting interpretations of depositional environment, age, and sequence stratigraphic framework. In this paper, we use both ichnofacies analysis and ichnostratigraphy to assert a dominant marine environment during deposition and an Early Silurian age for the lower and middle portions of the Furnas Formation. These results indicate the existence of an unconformity within the Furnas succession, which has profound implications for the stratigraphy of the Paraná Basin and for paleogeography of Gondwana during the early Paleozoic.

\section{Lower Paleozoic stratigraphy}

Lower Paleozoic strata in the Paraná Basin of southern Brazil (Fig. 1) have been grouped into the Ordovician-Silurian Rio Ivaí Group and Devonian Paraná Group (Assine et al., 1994; Assine, 1996), also referred as supersequences (Milani et al., 2007). The Rio Ivaí Group records deposition in fluvial to shallow marine environments (Alto Garças Formation), glacial-marine settings (Iapó Formation), and offshore marine realms (Vila Maria Formation) (Assine et al., 1998a, 1998b). Palynomorphs and marine macroinvertebrate body fossils indicate a Late Ordovician to Early Silurian (early Llandovery) age for the Iapó and Vila Maria formations (Assine et al., 1994; Popp et al., 1981; Burjack and Popp, 1981; Faria, 1982; Gray et al., 1985; Rodrigues et al., 1989; Borghi et al., 1996; Adôrno et al., 2016).

The overlying Paraná Group comprises the Furnas and the Ponta Grossa formations, the later subdivided into three members, from base to top: Jaguariaíva, Tibagi and São Domingos (Lange and Petri, 1967). The Ponta Grossa Formation is very fossiliferous and a Devonian age has been assigned based on macrofossils (brachiopods, trilobites and plants) and palynomorphs (Grahn, 1992 and Grahn et al., 2010, 2013). Paleoenvironments include inner to outer shelf marine settings (Clarke, 1913; Lange and Petri, 1967; Melo, 1988; Grahn, 1992; Rodrigues et al., 2003; Bosetti et al., 2011, 2013; Grahn et al., 2013; Horodyski et al., 2014; Matsumura et al., 2015; Sedorko et al., 2017). The Tibagi Member records a progradational event between the Emsian and Eifelian maximum-flooding surfaces (Assine et al., 1998c).

The Furnas Formation, subject of this research, is a very uniform unit in terms of stratigraphic stacking and thickness. The absence of body fossils and the dominance of cross-bed sets were strong arguments to interpret the Furnas sandstones as products of deposition in fluvial braided systems (Northfleet et al., 1969; Schneider et al., 1974; Popp and Barcellos-Popp, 1986; Melo, 1988; Zalán et al., 1987; Rodrigues et al., 1989; Coimbra et al., 1995; Pereira and Bergamaschi, 1996; Pereira et al., 1998). The unit also has been interpreted as shallow marine (Maack, 1946, 1947; Petri, 1948; Almeida, 1954; Sanford and Lange, 1960; Bigarella et al., 1966; Lange and Petri, 1967; Bigarella and
Salamuni, 1967; Petri and Fúlfaro, 1983; Bigarella, 1973; Borghi, 1993; Assine, 1996; Bergamaschi, 1999) based on wide geographic distribution and lithologic uniformity.

A tide-dominated shallow marine environment was interpreted for most of the Furnas succession by Assine (1999) based on the presence of tide-dominated facies associations, numerous levels of conglomerate lag deposits on ravinement surfaces, and many pavements with trace fossils, including Cruziana and Rusophycus. Marine ichnofacies were confirmed by later investigations (Fernandes et al., 2000; Netto et al., 2012, 2014). Supported by a detailed stratigraphic and sedimentologic approach, Assine (1999) recognized three distinct successive facies associations and subdivided the Furnas Formation into three informal units (lower, middle and upper).

Fossils from primitive plant Cooksonia (Rodrigues et al., 1989; Mussa et al., 1996; Gerrienne et al., 2001) and palynomorphs (Grahn et al., 2010) were found in the upper unit, $20-30 \mathrm{~m}$ below the contact with the overlying Ponta Grossa Formation, and attest to an Early Devonian age (late Lochkovian) for the uppermost section of the Furnas Formation. However, the age of the lower and middle units remains uncertain because no body fossils or microfossils have been found therein, and different ages have been assumed for those strata; e.g., Late Silurian to Lochkovian (Assine, 1999), Late Silurian (Borghi, 1993) or even Early Silurian (Zalán et al., 1987).

This uncertainty makes it difficult to establish a reliable stratigraphic framework for the Silurian-Devonian sequences of the Paraná Basin (Fig. 1B). Understanding stratigraphic cycles and basin evolution is problematic because different stratigraphic proposals involve age ambiguity and disparate views concerning key surfaces (e.g., presence or absence of unconformities). For example, the entire succession of the Furnas Formation has been considered by some as a single depositional sequence (Bergamaschi, 1999; Grahn et al., 2013), while others split the Furnas into two depositional sequences based on the sharp basal contact between the middle and upper units (Assine, 1996, 1999).

\section{Location, material, and methods}

Considering the importance of trace fossils to elucidate the abovementioned questions and uncertainties, we performed an integrated ichnologic and sedimentologic analysis in the Devonian beds exposed in the State of Paraná, southern Brazil. Our studies of the Furnas Formation focused on well-exposed sections at four localities (Fig. 1A), although other localities also were prospected. Data were collected directly in the field, along with samples for further laboratory analysis. Ichnofossils were described in association with sediment textures, physical sedimentary structures and facies geometry for facies analysis. Ichnologic analyses included identification of recurring trace fossils, to the maximum extent possible at the ichnospecies level; and quantification of degree of the bioturbation based on the scheme proposed by Reineck (1963; bioturbation scale, BS, ranging from $0=$ no bioturbation through $6=$ complete biogenic destruction of primary sedimentary fabric). Collected samples are deposited in the collections of the Museu da História Geológica do Rio Grande do Sul (Unisinos University) with the numbers ULVG-12017, ULVG-12018, ULVG-12019 and ULVG- 21020. The holotype of Rusophycus acacencis n. ichnosp. is deposited as a photo, with the number ULVG-12261a, which includes the paratypes ULVG-12261b and ULVG-12261c.

Ichnotaxa are described in alphabetical order. Trace fossil descriptions were based only on field observations, except for Arthrophycus alleghaniensis, specimens of which were also examined in detail in the laboratory (samples ULVG-12017, ULVG-12018, ULVG-12019 and ULVG-12020). Trace fossils originally described as Furnaisichnus langei Borghi and Fernandes, 2001 were here included in Didymaulyponomos rowei. The trace fossil Rusophycus acacensis n. ichnosp. were also described, considering that no formal description of these structures has previously been provided in the trace fossil literature. Systematic descriptions of both latter ichnospecies are presented in Appendix A. 


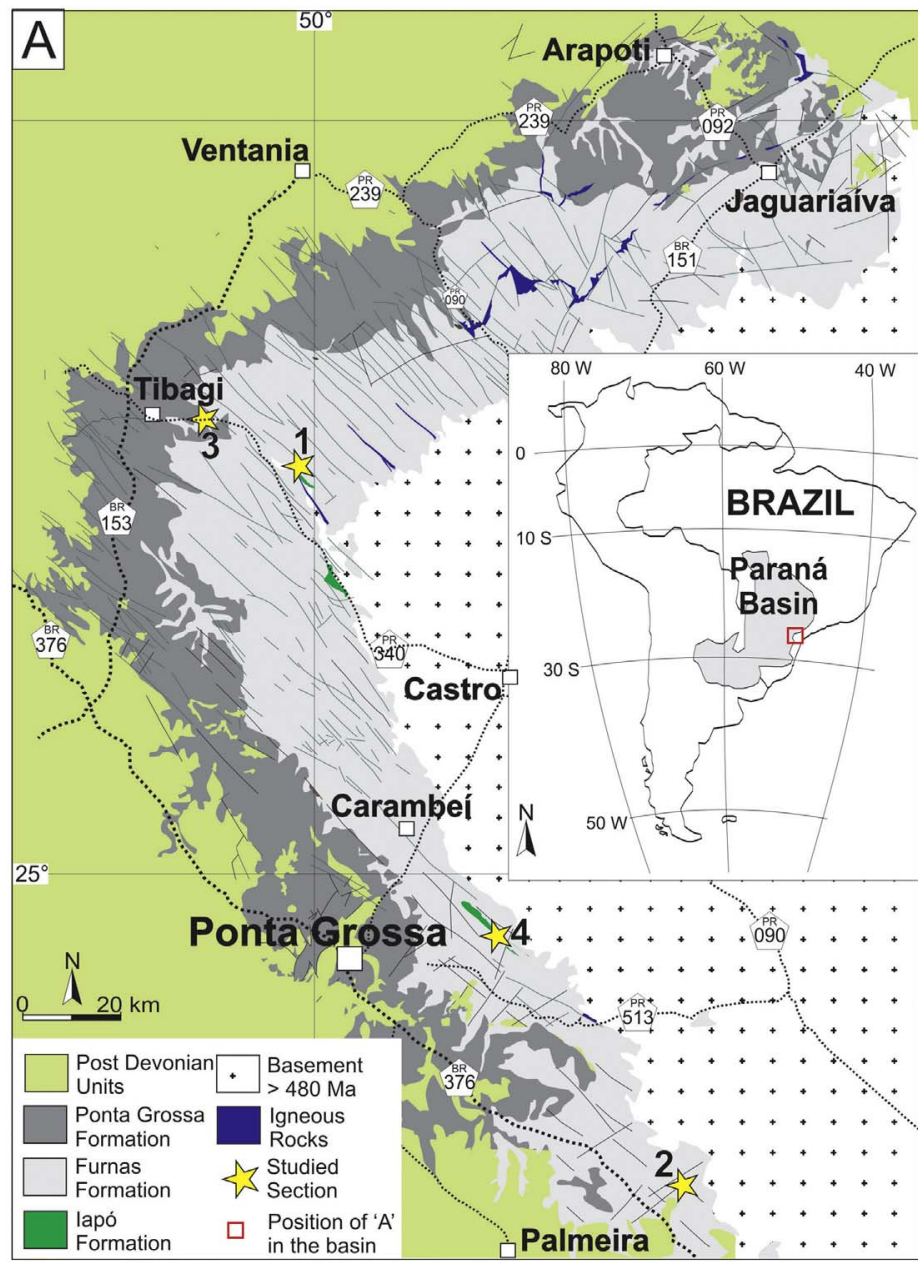

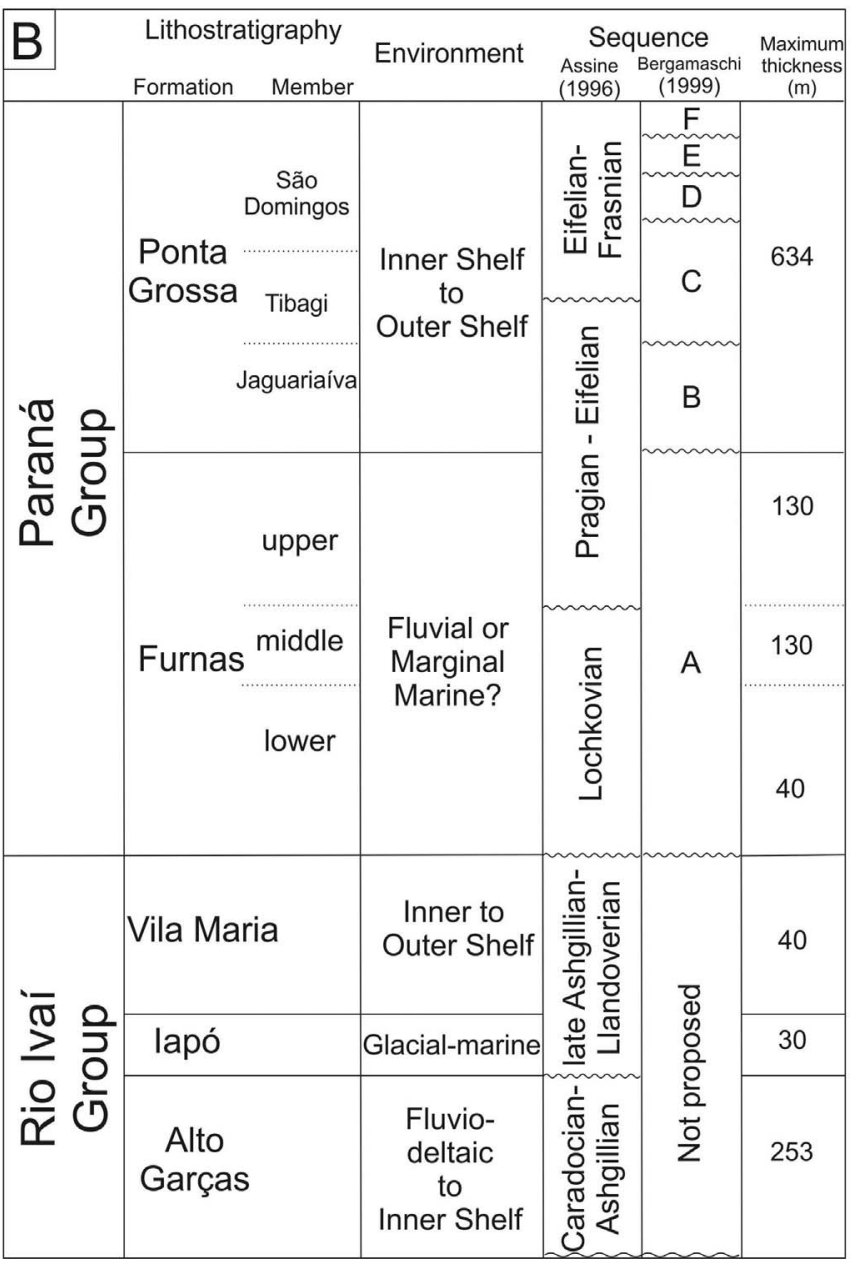

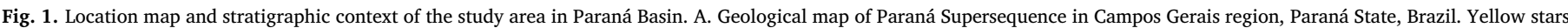

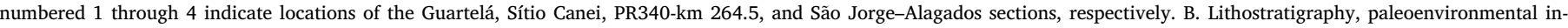

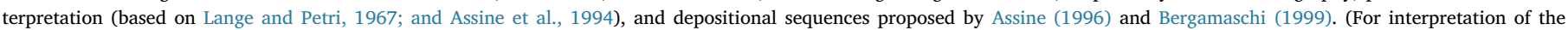
references to color in this figure legend, the reader is referred to the web version of this article.)

\section{Ichnofossil and ichnofacies of Furnas Formation}

Seventeen ichnotaxa are recognized in the Furnas Formation in the Campos Gerais region, most of them at the ichnospecies level. Associations of two or more ichnospecies in the same bed are common, and some transitional and compound forms locally occur. Recurring assemblages of these ichnotaxa led to the identification of two ichnofacies - Skolithos and proximal Cruziana ichnofacies.

\subsection{Trace fossil descriptions}

\subsubsection{Arenicolites isp. Salter, 1857 (Fig. 2A)}

Simple, vertical to oblique, U-shaped, unlined, unbranched burrows. Arenicolites is manifested on bedding planes as two circular apertures and in cross section by parallel U-limbs with no evidence of a spreite. Burrow diameter and limb separation range from 4 to $12 \mathrm{~mm}$ and 15 to $45 \mathrm{~mm}$, respectively. Arenicolites generally is interpreted as a dwelling structure of filter-, suspension- or deposit-feeding organisms, mainly polychaetes, but also crustaceans and insects (Bromley, 1996).

\subsubsection{Arthrophycus alleghaniensis Harlan, 1831 (Fig. 2B-D)}

Gently recurved, horizontal to slightly inclined, regularly annulated burrows with nearly circular to square cross sections, compacted walls, and fills similar to the host sediment. Apparent lateral branches radiate on both sides of the main axis. In cross section, these palmate structures appear as vertical stacks of crescentic backfill lamellae (i.e., as retrusive spreite structures; Fig. 2B, C). Annulae are pronounced on bottoms of burrows and less discrete on tops. Burrow diameters range from 5 to $15 \mathrm{~mm}$, with an average of $10 \mathrm{~mm}$.

Arthrophycus alleghaniensis was previously reported by Fernandes et al. (2000) from the Sítio Canei section. However, when Neto de Carvalho et al. (2002) commented on this occurrence, they referred to these traces as Arthrophycus lateralis, which differs from A. alleghaniensis in several aspects. In A. lateralis, branches are preferentially arranged to one side of the main axis, crescentic backfill lamellae are horizontal rather than vertical, and the spreiten are protrusive rather than retrusive (Seilacher, 2007). Seitz (2010) noted that specimens illustrated and described by Fernandes et al. (2000) correspond to A. alleghaniensis, which is supported by the current study. Arthrophycus reflects detritusfeeding activity of worm-like organisms or arthropods (Seilacher, 2000; Rindsberg and Martin, 2003; Brandt et al., 2012). McCoy et al. (2012) described a fossil arthropod, Pleuralata spinosa, associated with A. alleghaniensis, suggesting that the tracemakers of some ichnospecies of Arthrophycus could belong to a group of protostome animals known as Ecdysozoa.

\subsubsection{Arthrophycus brongniartii Harlan, 1832 (Fig. 2E)}

Horizontal, straight to sinuous burrows with regularly spaced external lower surface annulae along the main axis and fills similar to the host sediment. Burrows locally exhibit false branching. The specimens found in the deposits of Furnas Formation are preserved in full relief but locally are exposed on bedding-parallel surfaces (Fig. 2E). Burrow axes 

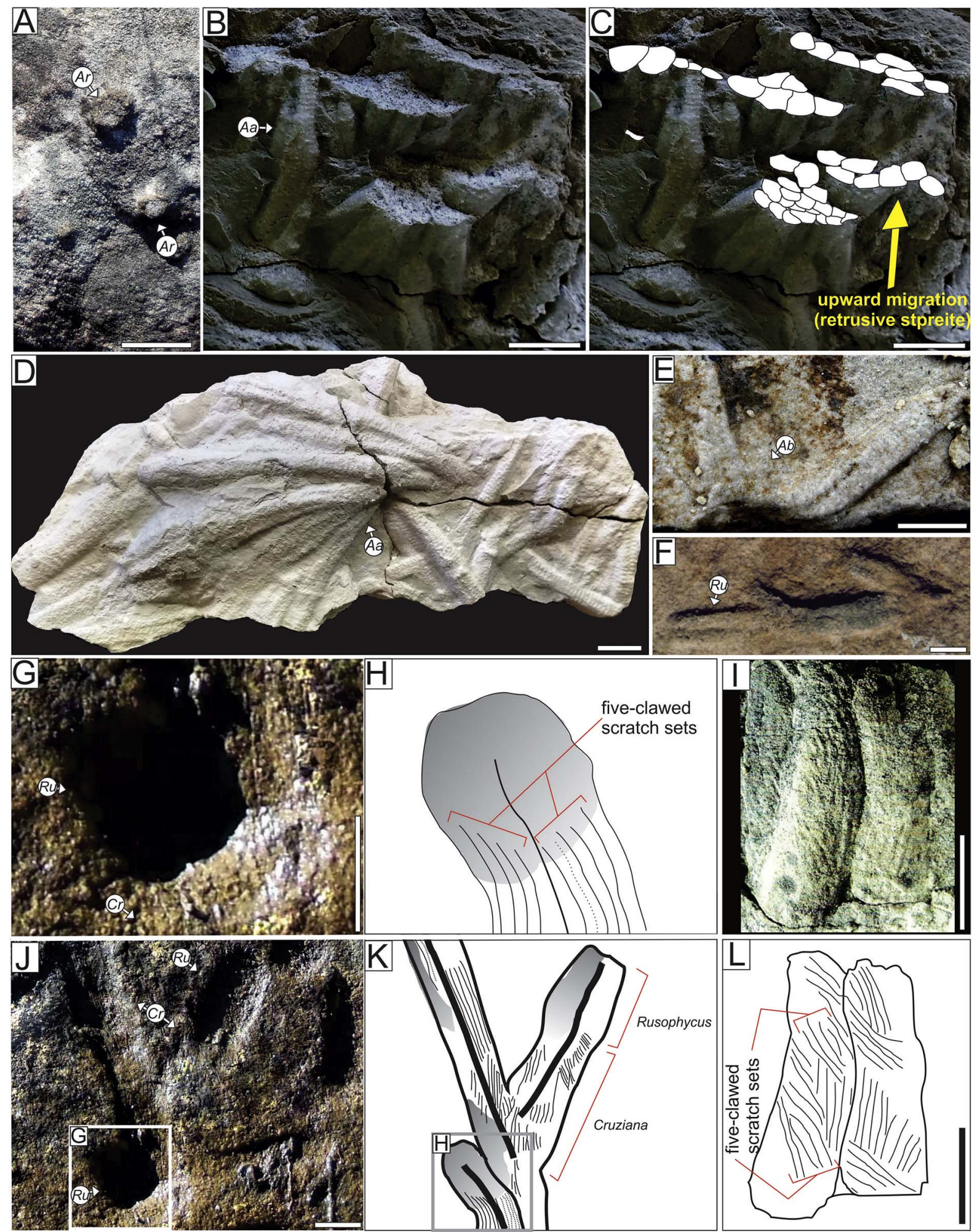

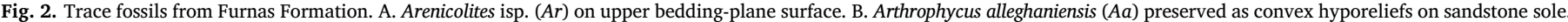

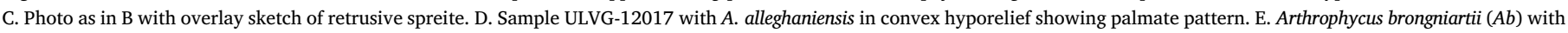

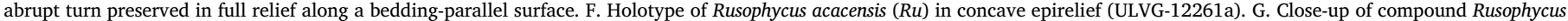

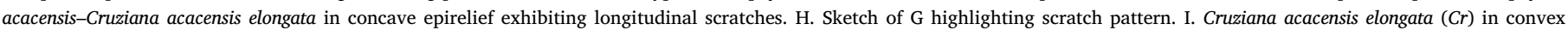

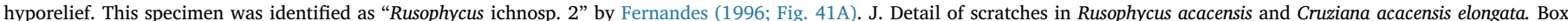

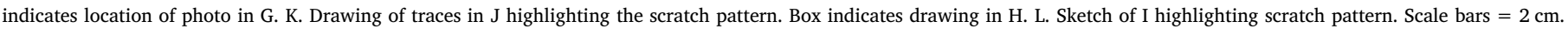

exhibit abrupt turns with no evidence of parallelism (sensu Rindsberg and Martin, 2003). This ichnospecies differs from A. alleghaniensis and A. lateralis mainly by the absence of prominent branching. Although $A$. brongniartii is similar in general character to A. minimus, the latter ichnotaxon has less pronounced annulae and is smaller (Mángano et al., 2005). A. parallelus is characterized by parallel arrangement of traces, which is absent in our occurrences. 


\subsubsection{Cruziana acacensis elongata Seilacher, 2007 (Fig. 2F-I)}

Elongate, bilobate symmetric burrows with medial ridges marked by transverse to longitudinal scratches. These bilobed traces are preserved in concave epirelief. Furrows exhibit a discrete median ridge (2 to $5 \mathrm{~mm}$ wide) with scratches, which occur in sets of five (Fig. $2 \mathrm{H}-\mathrm{I}$ ). The traces are typically 5-9 $\mathrm{cm}$ long, but some reach $16 \mathrm{~cm}$. These structures are aligned with Cruziana acacensis elongata based on their straight axes and length/width ratios of $\sim 3$ (Seilacher, 2007). Seilacher (2007, p. 198) identified this ichnosubspecies in the Furnas Formation and noted that the same tracemaker made both Cruziana and short rusophyciform burrows (compound trace fossils), identified as Rusophycus cf. acacensis by Netto et al. (2014) (Fig. 2F, G).

The tracemakers of both Cruziana and Rusophycus are bilaterally symmetrical organisms, most probably arthropods (Donovan, 2010). These ichnogenera have been reported in Triassic continental deposits (Bromley and Asgaard, 1979; Zonneveld et al., 2002). However, in the Paleozoic record, they occur exclusively in marine deposits. With the exception of Cruziana problematica and Rusophycus carbonarius, Paleozoic Cruziana and Rusophycus are generally attributed to trilobites (Goldring, 1985; Fortey and Seilacher, 1997).

\subsubsection{Cylindrichnus isp. Toots in Howard, 1966 (Fig. 3A)}

Concentrically laminated, vertical burrows filled with sediments similar to the host sediment. Specimens, observed only on bedding planes, range from 6 to $15 \mathrm{~mm}$ in diameter. Cylindrichnus is interpreted as a permanent dwelling structure of suspension-feeding organisms (Frey and Howard, 1990). This ichnogenus is common in shoreface to offshore environments, and, thus, represents a common component of the Skolithos and Cruziana ichnofacies (Frey and Howard, 1985; Vossler and Pemberton, 1989).

\subsubsection{Didymaulichnus lyelli Rouault, 1850 (Fig. 3B-C)}

Unbranched, unornamented, smooth-walled, bilobed trails with a narrow median groove (in hyporelief) or crest (in epirelief). Didymaulichnus lyelli occurs mainly in Paleozoic strata and is a common facies-crossing trace fossil (Fillion and Pickerill, 1990), possibly produced by mollusks (mainly gastropods; Glaessner, 1969; Hakes, 1976) or trilobites (Crimes, 1970; Bradshaw, 1981).
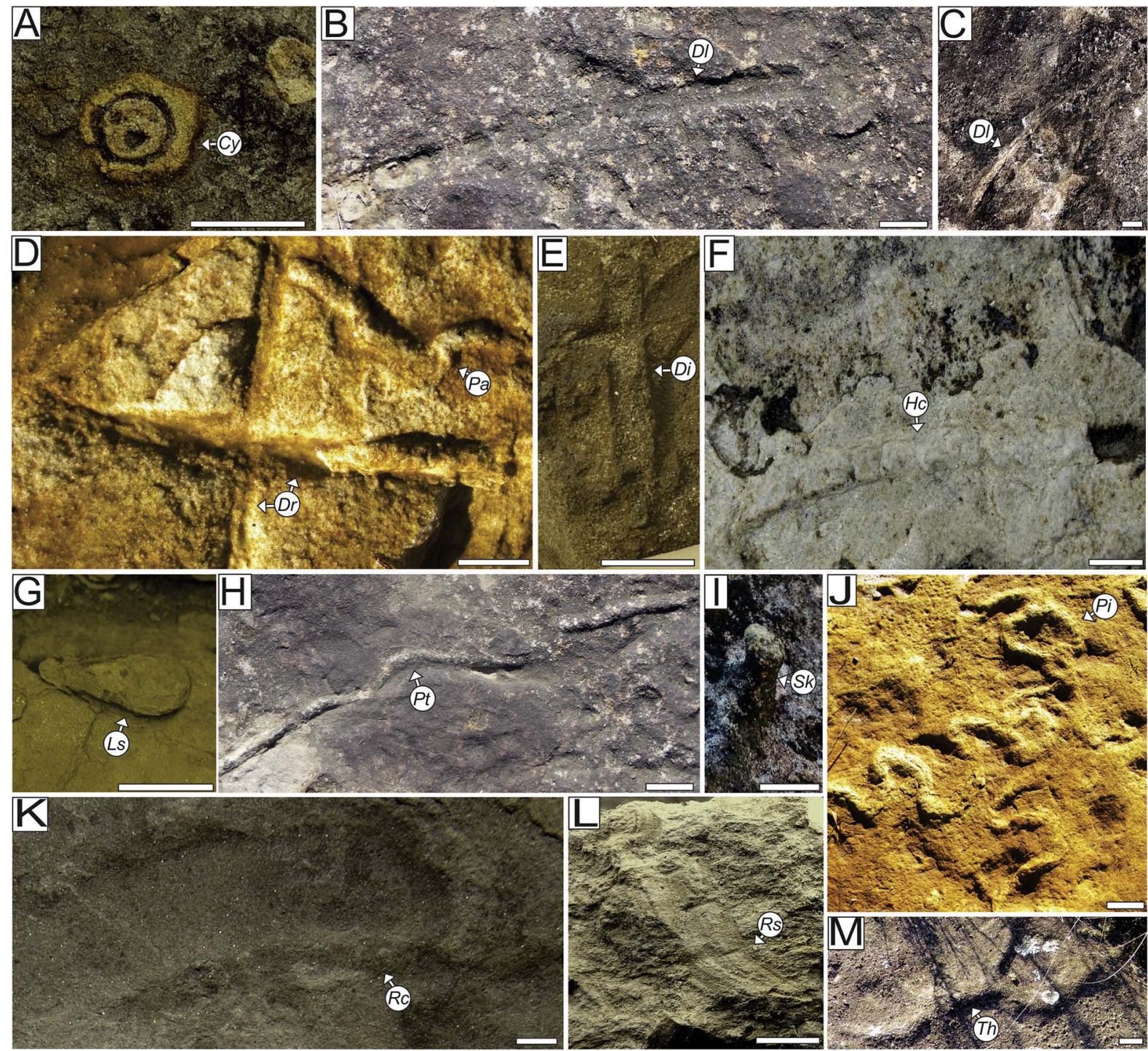

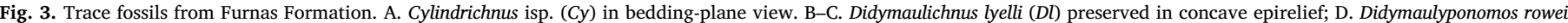

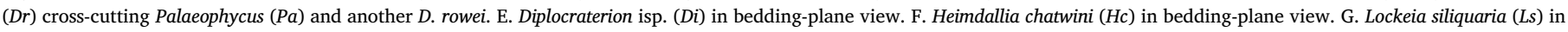

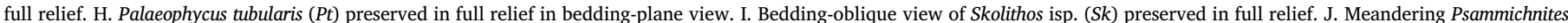

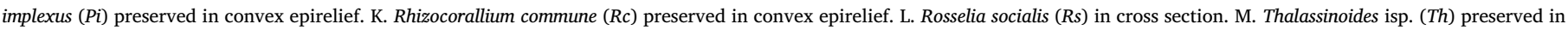
full relief in bedding-plane view. Scale bars $=2 \mathrm{~cm}$. 
4.1.7. Didymaulyponomos rowei Bradshaw, 1981 (Fig. 3D; see Appendix A)

These structures appear as horizontal, straight to sinuous, unbranched, and unornamented endichnial burrows with median furrows in their lower parts. Fills are structureless and similar or locally finer than surrounding sediment. Specimens are generally equidimensional with respect to width and height (10 to $15 \mathrm{~mm}$ ) and may exceed $1 \mathrm{~m}$ in length.

Bradshaw (1981) argued that Didymaulyponomos represents feeding or dwelling activity of arthropods below the sediment surface. Trewin and MacNamara (1994) observed that Didymaulichnus is quite similar to the bottom half of a Didymaulyponomos burrow and suggested that an erosional event may be involved in Didymaulichnus preservation. Despite these similarities, both ichnogenera names remain valid. Buatois et al. (2017) placed this trace into their architectural design category "passively filled horizontal burrows", similar to Palaeophycus. Coincidentally, occurrences of $D$. rowei in the Furnas Formation are associated with Palaeophycus.

\subsubsection{Diplocraterion isp. Torell, 1870 (Fig. 3E)}

Vertical U-shaped, unbranched burrows with spreiten; fills are similar to the host sediment. Diplocraterion was seen only on bedding planes, permitting identification only at the ichnogenus level. Specimens appear as paired apertures linked by a protrusive spreite; apertures are normally $5-15 \mathrm{~mm}$ in diameter, and spaced between 25 and $50 \mathrm{~mm}$ apart. This ichnogenus represents the dwelling structure of suspension- or detritus-feeding organisms, possibly crustaceans or polychaetes (Turner et al., 1981; Bromley, 1996; Savrda and Nanson, 2003; Goldring et al., 2005; Seilacher, 2007).

\subsubsection{Heimdallia chatwini Bradshaw, 1981 (Fig. 3F)}

Vertical spreite-bearing burrows that appear in bedding-plane view as unbranched ribbons formed of vertical or inclined packets of sediment. This trace fossil was seen mainly in bedding-plane view; vertical spreiten are only locally exposed. Packets of sediment resulted from the progressive lateral migration of the tracemaker. Bradshaw (1981) proposed that Heimdallia may reflect the activity of a crustacean-like animal in search of food.

\subsubsection{Lockeia siliquaria James, 1879 (Fig. 3G)}

Almond-shaped, unornamented burrows with fills similar to host sediment. L. siliquaria includes most of isolated almond-shaped traces (Seilacher and Seilacher, 1994). L. cordata differs from L. siliquaria by having larger and rounder shape (Rindsberg, 1994). Lockeia is interpreted as a resting trace produced by bivalve mollusks (Osgood, 1970).

\subsubsection{Palaeophycus tubularis Hall, 1847 (Fig. 3H)}

Thinly lined, horizontal to slightly inclined, unbranched, straight to slightly curved cylindrical burrows with structureless fills similar to the matrix. Palaeophycus tubularis differs from $P$. heberti by having a thinner wall and from other ichnospecies ( $P$. striatus, $P$. sulcatus, and $P$. alternatus) by the absence of striae (Pemberton and Frey, 1982). Rindsberg (2012) demonstrated that $P$. alternatus and $P$. striatus may be variants of the same structure, and additional studies are necessary to solve those ichnotaxonomic problems. This ichnogenus is considered to be a dwelling structure produced by suspension-feeding or predaceous organisms, possibly polychaetes. Glycera (a glycerid polychaete) was suggested as one potential tracemaker (Pemberton and Frey, 1982; Fillion and Pickerill, 1990).

\subsubsection{Psammichnites implexus Rindsberg, 1994 (Fig. 3J)}

Straight to meandering, horizontal, flat trace with subtriangular to elliptical cross-section, faint meniscate backfill and a dorsal ridge preserved as a groove. The bottom of the trace may be unilobed or bilobed. Burrow width is nearly constant (normally 22 to $28 \mathrm{~mm}$, although forms $10 \mathrm{~mm}$ wide are also present), but increases slightly in turns
(Fig. 3J), particularly where burrows exhibit phobotactic tendencies similar to those observed by Mángano et al. (2003). Despite phobotactic tendencies, crosscutting is relatively common. Psammichnites is attributed to feeding activities of vagile infaunal animals, probably gastropods or other organisms with a siphon device (Seilacher, 1997).

\subsubsection{Rhizocorallium commune Schmid, 1876 (Fig. 3K)}

Horizontal, straight to sinuous, unornamented, unbranched, Ushaped burrows with protrusive spreite. Rhizocorallium commune differs from firmground $R$. jenense by the presence of unornamented walls and an actively filled spreite (Knaust, 2013). $R$. commune is attributed to suspension- or deposit-feeding activity, probably by polychaetes or crustaceans (Knaust, 2013).

\subsubsection{Rosselia socialis Dahmer, 1937 (Fig. 3L)}

Vertical to inclined, spindle- to funnel-shaped structures with concentrically laminated fine-grained walls surrounding a central shaft. In some levels, Rosselia occurs in dense concentrations (i.e., the crowded Rosselia ichnofabric of Netto et al., 2014). Nara (1995) described two forms of $R$. socialis. Spindle-shaped forms are the norm, while truncated funnel-shaped forms predominate below erosional surfaces. Rosselia is attributed to dwelling or feeding activity of suspension- or detritusfeeding worms, probably terebellid polychaetes (Nara, 1995).

\subsubsection{Rusophycus acacensis $n$. ichnosp. (Fig. 2F-I; Appendix A)}

Bilobed ovate, symmetrical traces preserved in concave epirelief. Specimens are between 15 and $25 \mathrm{~mm}$ wide and 20 to $55 \mathrm{~mm}$ long, with a length/width ratio of 3 . Furrows exhibit a distinct medial ridge, locally with scratches, and occur either in association with or forming compound trace fossils with Cruziana acacensis elongata. Paleozoic Rusophycus is generally attributed to trilobite activity, probably reflecting resting behavior (Seilacher, 2007).

\subsubsection{Skolithos isp. Haldeman, 1840 (Fig. 3I)}

Vertical to slightly inclined, cylindrical or subcylindrical, unlined, unbranched burrows with fills similar to the host sediment. Occurrences of Skolithos in Furnas Formation are poor preserved or limited to simple apertures on bedding-plane surfaces, precluding identification at the ichnospecific level. Skolithos is commonly produced by worm-like organisms, possibly polychaetes (Seilacher, 1967; Pemberton and Jones, 1988; Herringshaw et al., 2010).

\subsubsection{Thalassinoides isp. Ehrenberg, 1944 (Fig. 3M)}

Branched systems of cylindrical, smooth-walled, straight to slightly curved, unlined burrows with enlarged branch junctions and fills similar to host sediment. Burrow diameters average $\sim 30 \mathrm{~mm}$. This ichnogenus is normally attributed to dwelling and feeding activities of decapod crustaceans. However, these burrows also may have been produced by worm-like organisms or small crustaceans during the Paleozoic, as suggested by Myrow (1995).

\subsection{Ichnofacies}

Based on recurring trace fossil associations, two ichnofacies can be identified in the Furnas Formation: the Skolithos Ichnofacies and proximal Cruziana Ichnofacies.

Trace fossil associations assigned to the Skolithos Ichnofacies are dominated by vertical traces, mainly Skolithos, Arenicolites, Diplocraterion and Cylindrichnus, although Palaeophycus tubularis and Thalassinoides are present locally. This ichnofacies records preferential colonization by suspension feeders in relatively high-energy settings (e.g., Frey, 1990). Trace fossil associations assigned to the proximal Cruziana Ichnofacies are dominated by epigenic and mainly horizontal endogenic structures produced chiefly by deposit feeders. Intervals in the Furnas Formation characterized by this ichnofacies contain one or more (as many as six) of the following ichnotaxa: Didymaulyponomos 


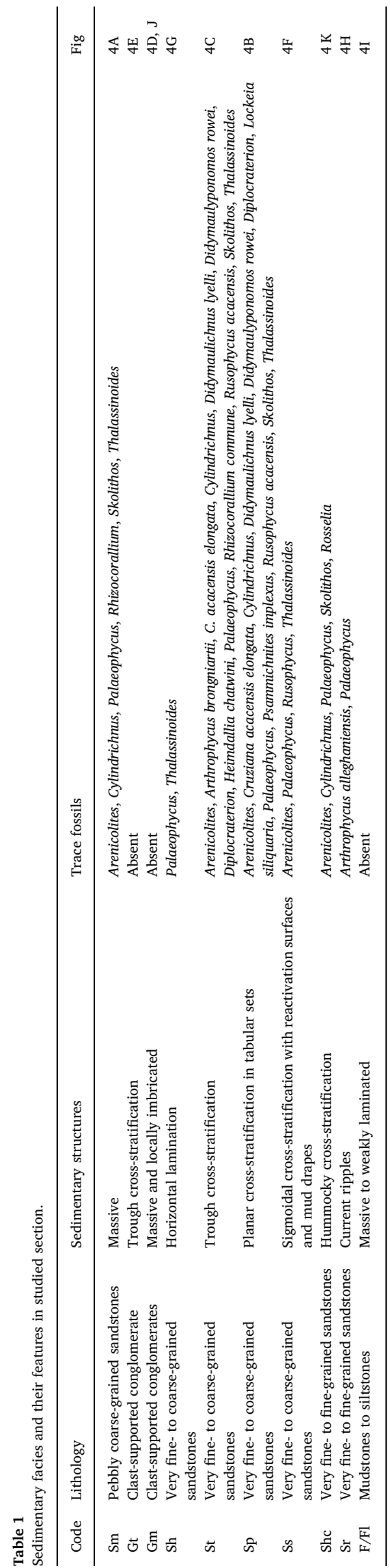

rowei, Heimdallia chatwini, Arthrophycus brongniartii, A. alleghaniensis, Rhizocorallium commune, Palaeophycus tubularis, Thalassinoides, Rosselia socialis, Didymaulichnus lyelli, Psammichnites implexus, Cruziana acacensis elongata, Rusophycus acacensis, and Lockeia siliquaria. Taken together, these trace fossil assemblages reflect deposition in overall comparatively low-energy environments. However, localized co-occurrences of Skolithos indicate at least periodically enhanced bottom currents, and rare intervals containing stacked Rosselia (see below) reflect episodic rapid deposition.

\section{Integrated sedimentology and ichnology}

Based on detailed field descriptions of rocks, textures, geometry, and physical sedimentary structures, ten lithofacies were recognized in the Furnas Formation exposed at the four study localities (Table 1). The stratigraphic distributions of lithofacies and associated trace fossils through the Furnas Formation at each of the study localities are shown in Fig. 5.

\subsection{Lower unit}

The lower Furnas Formation is exposed at all localities except the PR 340 section (Fig. 5). This unit is $30-40 \mathrm{~m}$ thick and directly overlies Cambrian to Ordovician volcanic rocks of the Castro Group (Assine, 1996) at Guartelá and Sítio Canei, and Ordovician to Silurian diamictites of the Iapó Formation (Rio Ivaí Group; Assine et al., 1998a) at São Jorge-Alagados.

This unit is dominated by thin $(<50 \mathrm{~cm})$, lenticular, massive pebbly coarse-grained sandstones (facies Sm; Fig. 4A), but also includes 0.4 to $2.0 \mathrm{~m}$-thick tabular sets of planar cross-bedded, medium- to coarse-grained sandstones (facies Sp; Fig. 4B) and trough cross-stratification (facies St; Fig. 4C). Subordinate rocks include centimetric, massive, locally imbricated clast pavements (facies Gm; Fig. 4D) and trough cross-bedded clast-supported conglomerates (facies Gt; Fig. 4E).

Trace fossils are present locally in all above-described dominant lithofacies, although the bioturbation in all cases is low to moderate (BS 1 to 3; Fig. 5). Assemblages representing the proximal Cruziana Ichnofacies are dominated by Palaeophycus, Thalassinoides, and, locally, Rusophycus. However, Skolithos Ichnofacies assemblages with Skolithos, Arenicolites, and Cylindrichnus also are common in pebbly sandstones (lithofacies $\mathrm{Sm}$ ) and are a subordinate component in the cross-bedded sandstones (lithofacies Sp and St) (Fig. 5).

\subsection{Middle unit}

The middle unit is represented in all sections except for the PR 340 locality. This unit is $\sim 130 \mathrm{~m}$ thick at Guartelá and $\sim 95 \mathrm{~m}$ thick at SãoJorge-Alagados; the Sítio Canei section exposes only the lower $\sim 20 \mathrm{~m}$ of the unit. At all three localities, the transition from the lower to the middle Furnas Formation is gradational and generally reflects a finingupward trend (Fig. 5).

This unit is dominated by fine- to coarse-grained planar and trough cross-bedded sandstones, 0.3 to $2.5 \mathrm{~m}$ thick (facies $\mathrm{Sp}$ and $\mathrm{St}$ ). Subordinate lithofacies include fine- to coarse-grained sandstones with sigmoidal cross-bed sets having reactivation surfaces (facies Ss; Fig. 4F) and horizontal to subhorizontal stratification (facies Sh; Fig. 4G), rippled fine-grained sandstones (facies Sr; Fig. $4 \mathrm{H}$ ), and 0.2 to $1.8 \mathrm{~m}$-thick massive and crudely laminated mudstones (facies F and Fl; Fig. 4I). Noteworthy is the presence of cross-bed sets up to $4 \mathrm{~m}$ thick, exhibiting foreset mud drapes and internal reactivation surfaces.

As in the lower unit, bioturbation is common but of low to moderate intensity (BS 1-3); most intervals (facies St, Sp, Ss, and Sh) are dominated by low-diversity proximal Cruziana Ichnofacies assemblages, and some (facies Sp and St) locally include Skolithos Ichnofacies suites (Fig. 5). Occurrences of proximal Cruziana Ichnofacies assemblages include one or a few of the following ichnotaxa: Palaeophycus tubularis, 

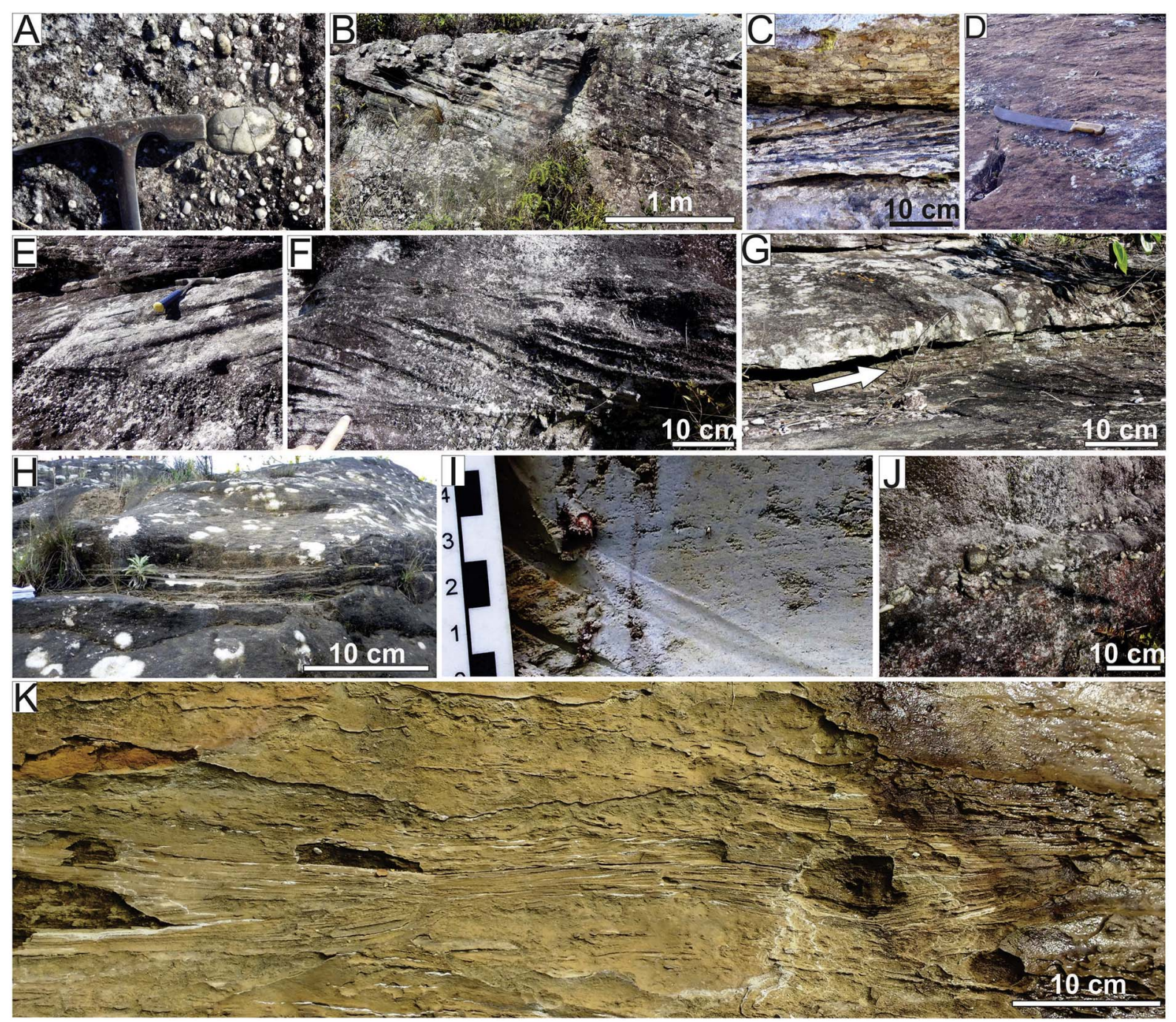

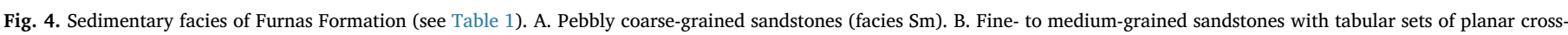

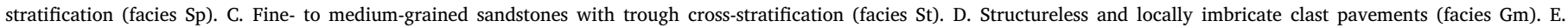

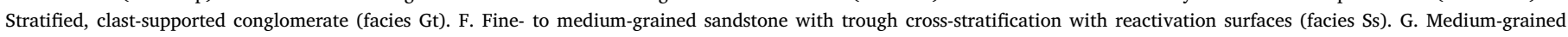

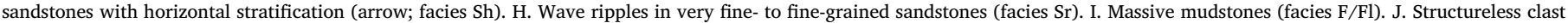
pavements (facies Gm at middle-upper units contact). K. Fine-grained sandstones with hummocky cross-stratification (facies Shc).

Didymaulichnus lyelli, Thalassinoides, Cruziana acacensis elongata, Didymaulyponomos rowei, Heimdallia chatwini, Lockeia siliquaria, Psammichnites implexus, Rhizocorallium commune, Rusophycus acacensis, and Arthrophycus brongniartii. Skolithos Ichnofacies assemblages include Arenicolites, Skolithos, Cylindrichnus and Diplocraterion. Rippled sandstones (facies Sr) contain Palaeophycus and locally Arthrophycus alleghaniensis. Massive mudstones and siltstones (facies F/Fl) lack trace fossils altogether.

\subsection{Upper unit}

The upper unit is represented at all sections except at Sítio Canei. It is $\sim 130 \mathrm{~m}$ thick at Guartelá, while only the uppermost $17 \mathrm{~m}$ and the lowermost $2 \mathrm{~m}$ are exposed at PR 340 and São Jorge-Alagados, respectively (Fig. 5). The base of the upper Furnas Formation is marked by a sharp planar erosive ravinement surface, overlain by thin clastsupported conglomerate beds (Fig. 4J).

This unit is dominated by medium- to coarse-grained sandstones with planar (lithofacies Sp), trough (facies St), or sigmoidal cross bedding (facies Ss) in sets ranging from 0.5 to $5.0 \mathrm{~m}$ in thickness. Sandstones with sigmoidal cross bedding contain common mud drapes.

Subordinate facies include thin, locally imbricated clast pavements (facies Gm), massive to weakly graded, conglomeratic sandstones (facies $\mathrm{Sm}$ ), trough cross-stratified, clast-supported conglomerates (facies $\mathrm{Gt}$ ), fine- to medium-grained hummocky cross-stratified sandstones (facies Shc; Fig. 4K), and massive mudstones (facies F). The last two lithofacies are generally restricted to the PR 340 section, in the upper parts of the upper unit. Mudstones at that level contain terrestrial fossil remains, including that of the primitive vascular plant Cooksonia (Gerrienne et al., 2001).

Most of the lithofacies in this unit are weakly bioturbated (BS $=1-2$ ) and contain trace fossil assemblages representing both the proximal Cruziana and Skolithos ichnofacies (Fig. 5). The former includes Palaeophycus, Thalassinoides, and locally Rhizocorallium commune or Didymaulichnus lyelli. The latter includes Skolithos, Arenicolites, and Cylindrichnus.

Hummocky cross-stratified sandstones (facies Shc) occur interbedded with shales at the very top of Unit III, in what Petri (1948) referred to as the "Transitional Beds" to the overlying Ponta Grossa Formation. The Transitional Beds are relatively highly bioturbated (BS 3-4), reflecting the dense emplacement of commonly stacked Rosselia (i.e., the Crowded Rosselia Ichnofabric, or CRI, of Netto et al., 2014) and localized co-occurrences of Cylindrichnus, Skolithos and/or Diplocraterion. 


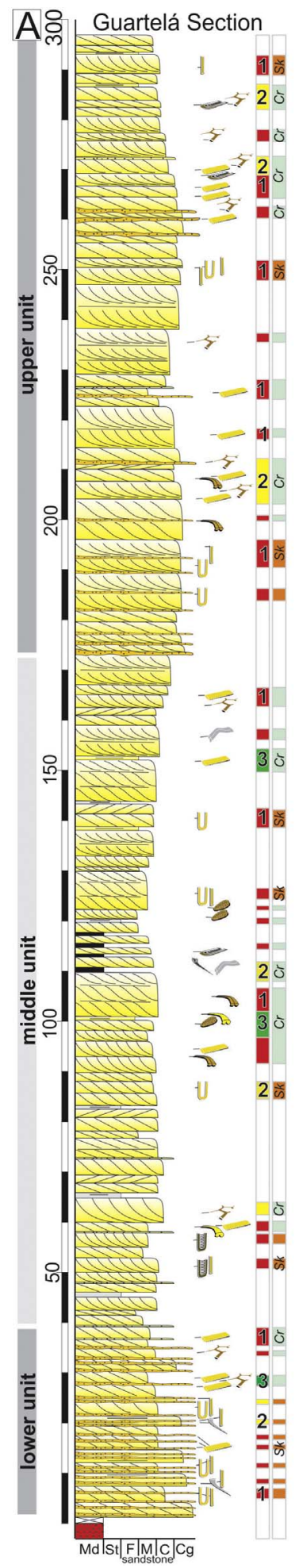

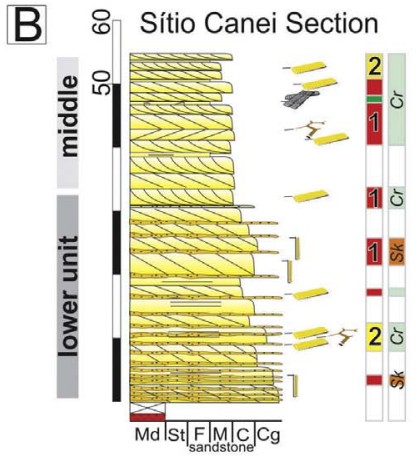

C Section of PR $340, \mathrm{~km} 264,5$

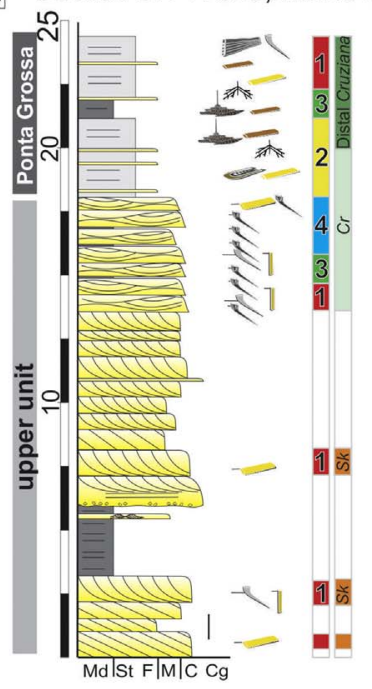

Legend

\begin{tabular}{|l|l}
\hline & Arenicolites isp. \\
Arthrophycus alleghaniensis & Arthrophycus brongniartii \\
Cruziana acacensis elongata \\
Cylindrichnus isp.
\end{tabular}

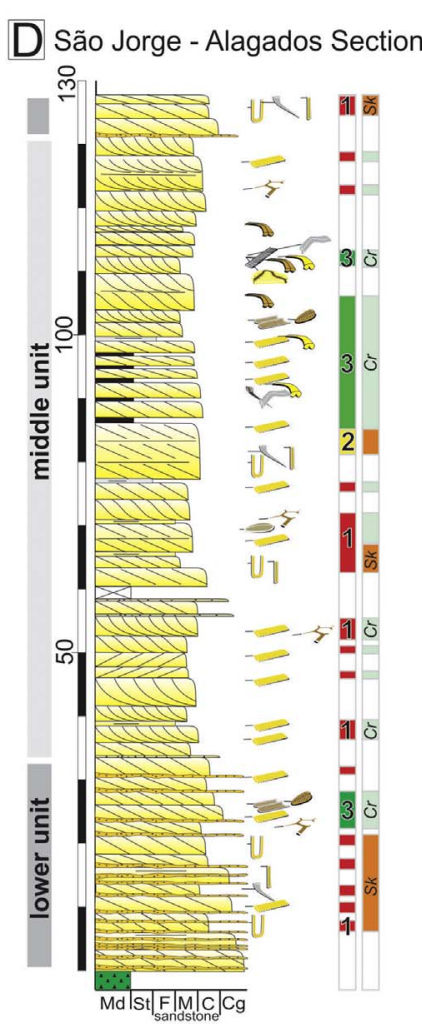

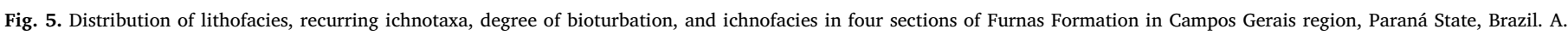
Canyon Guartelá section, Tibagi. B. "Sítio Canei" section, Palmeira. C. PR340 section, Tibagi; D. São Jorge-Alagados section, Ponta Grossa.

\section{Paleoenvironmental interpretation}

Based on detailed stratigraphic and sedimentologic data, supported by the presence of trilobite traces, Assine $(1996,1999)$ interpreted the Furnas Formation as representing marine environments. Our sedimentologic and ichnologic observations overwhelmingly support that interpretation, particularly the detailed trace fossil analysis, as discussed below.

\subsection{Physical sedimentologic evidence}

Sedimentary facies associations are consistent with high-energy, tide-dominated and, to a lesser extent, storm-influenced, shallow marine depositional environments. Laterally extensive tabular crossbed sets, common in sandstones throughout the Furnas Formation (Fig. 4B), are inconsistent with fluvial braided systems. In contrast, tabular sets may be common in tidal regimes, reflecting the migration 


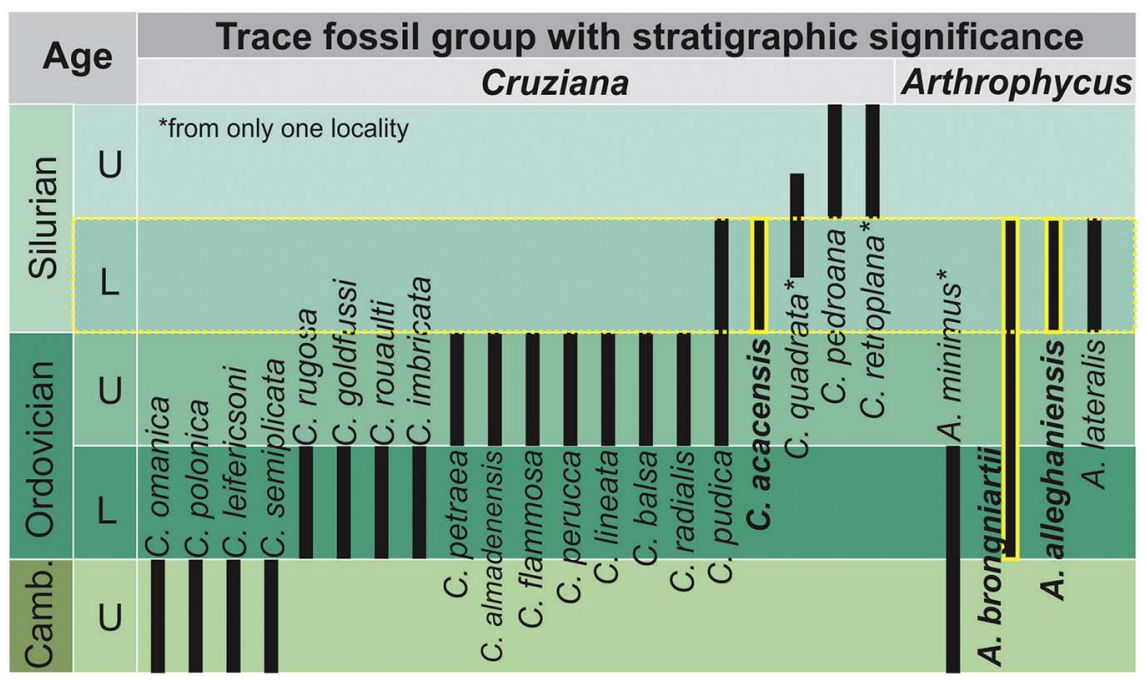

Fig. 6. Chronostratigraphic range of ichnospecies of Cruziana and Arthrophycus (ichnotaxa present in lower and middle units of Furnas Formation are highlighted in bold) (modified after Seilacher, 2007; Brandt et al., 2010; Buatois and Mángano, 2011). of elongate, straight-crested, flat-topped subaqueous bars or sandwaves in areas of high tidal asymmetry (Dalrymple and Choi, 2007). Specific lithofacies also provide evidence for significant tidal influence. These include sandstones with sigmoidal cross-bedding (facies Ss; Fig. 4F) and mud drapes, which occur with increasing frequency upward through the middle and upper units (Fig. 5). These sets reflect tide-mediated migration of bedforms in areas of higher tidal asymmetry (Reading, 1996). While a tidal signal is prevalent throughout most of the Furnas Formation, the hummocky cross-stratified sandstones (facies Shc) observed at the top of the section at the PR 340 locality (the aforementioned Transitional Beds of Petri, 1948) reflect a storm-influenced marine setting. As previously suggested by Netto et al. (2014), facies Shc likely reflects deposition in lower shoreface or transitional offshore settings.

\subsection{Ichnologic evidence}

Ichnofossil assemblages lend further support for the marine interpretation. Some of the recurring ichnotaxa found in the Furnas Formation have been recognized in continental as well as marine deposits, such as Palaeophycus, Didymaulichnus, and Skolithos (Bradshaw, 1981; Buatois et al., 1998; Buatois and Mángano, 2011). Other ichnotaxa, including Arenicolites, Cylindrichnus, and Rhizocorallium, also have been recognized in continental facies, but only in the post-Paleozoic stratigraphic record (Minter et al., 2016). Notably, throughout the Furnas Formation, such potentially facies-crossing ichnotaxa co-occur with other ichnotaxa that are regarded as indicative of marginal marine and marine conditions (e.g., Thalassinoides, Rusophycus, Cruziana, Arthrophycus, Psammichnites). Hence, ichnofossil assemblages at all levels indicate marine conditions.

The low intensities of bioturbation observed through the Furnas Formation overall reflect high-energy regimes. Ichnofossils likely were only emplaced during periods of relatively quiescence that provided windows for colonization by benthic organisms. Skolithos Ichnofacies assemblages reflect colonization under high-energy environmental conditions, while Cruziana Ichnofacies assemblages record colonization in quieter, deeper-water settings. The latter ichnofacies dominates in the middle unit, which is characterized by finer overall finer grain size and includes common interbedded fine-grained facies. The middle unit contains the most ethologically diverse ichnoassemblages. This likely reflects lower-energy regimes (and, perhaps, somewhat deeper water) than those associated with lower and upper units.

As noted above, the common stacked, funnel-shaped Rosselia in hummocky cross-stratified sandstones in "Transitional Beds" record equilibrium responses by stress-tolerant organisms to high-frequency storm depositional events (Netto et al., 2014).

In summary, sedimentologic and ichnologic observations of the Furnas Formation indicate deposition in moderate- to high-energy, strongly tide-influenced but locally storm-influenced marine environments, most likely in the lower shoreface to offshore transition. Depending on energy regime and available colonization windows, sediments were periodically inhabited by varied communities of suspension-, detritus-, deposit-feeding, and/or predaceous organisms.

\section{Ichnostratigraphic implications}

Aside from plant fossils found in thin, fine-grained facies in the upper unit (Mussa et al., 1996; Gerrienne et al., 2001), body fossils are absent in the Furnas Formation. The lack of body fossils is likely related to persistently high-energy conditions and sandy substrates unfavorable for preservation. These substrates were probably relatively permeable and saturated with oxygenated pore water, factors that are not conducive for body fossil preservation. Regardless of the cause, the absence of body fossils precludes traditional biostratigraphic studies. Fortunately, ichnofossils can assist in establishing age relations and chronostratigraphic framework.

\subsection{Furnas Formation ichnofossils as biostratigraphic indicators}

One of the commonly stated principles of ichnology is that most trace fossils have rather long geologic ranges and, hence, generally are of limited or no use in biostratigraphic analysis (e.g., Bromley, 1996; Buatois et al., 2002; Buatois and Mángano, 2011). However, for lower Paleozoic strata, certain ichnotaxa preserve morphological features that reflect behaviors and construction strategies that can be linked to specific groups of age-diagnostic trace makers and therefore can be applied as biostratigraphic indicators (Seilacher, 2007). Such trace fossils include Cruziana and the arthrophycids (Seilacher, 2000, 2007; Mángano et al., 2005; Buatois and Mángano, 2011) (Fig. 6).

Cruziana and Rusophycus were reported in previous investigations of the Furnas Formation (Fernandes, 1996; Assine, 1999; Seilacher, 2007; Netto et al., 2012). Three ichnotaxa with ichnostratigraphic significance are here documented: Cruziana acacensis elongata, Arthrophycus alleghaniensis, and $A$. brongniartii. Both Cruziana acacensis elongata and Rusophycus acacensis, which comprise the "acacensis group", were recognized here in the middle unit (São Jorge-Alagados section; Fig. 5). Seilacher (2007) recognized this group as a stratigraphic marker of the Lower Silurian (Fig. 6), a relationship corroborated by co-occurrences of ichnofossils and body fossils at other Gondwanan locations, in Benin and Argentina. 
Regarding the arthrophycids, Mángano et al. (2005) and Brandt et al. (2010) list five ichnospecies with ichnostratigraphic significance: A. brongniartii ( $=$ A. linearis), A. alleghaniensis, A. lateralis, A. minimus and A. parallelus (Fig. 6). Both A. brongiartii and A. alleghaniensis are present in the middle unit of Furnas Formation (in the São Jorge-Alagados and Sítio sections, respectively; Fig. 5). A. brongiartii is an indicator of the Lower Ordovician to Lower Silurian, while A. alleghaniensis is used as a guide fossil for the Lower Silurian (Seilacher, 2000, 2007; Buatois and Mángano, 2011). These relations are supported by other occurrences of these ichnospecies in fossiliferous strata reported mostly in Gondwanan terranes from Brazil, Argentina, Falkland/Malvinas Islands, Libya and Chad, with records recently reported from Laurasia (USA; Rindsberg and Martin, 2003; Mángano et al., 2005). Based on the discussion above, a Lower Silurian age can be assigned to the lower and middle units of the Furnas Formation.

The record of the "acacensis group" in Paraná Basin (Brazil) fills a geographic gap in Gondwana during the Lower Silurian, corroborating the idea of a possible transcontinental seaway (Seilacher, 2007), since this group was previously reported in Argentina (Jujuy Province) and North Africa. Besides the paleogeographic relevance, this revised sequence stratigraphic framework may have implications for hydrocarbon exploration in the Paraná Basin. Notably, once-contiguous lower Silurian strata in North Africa are important source and reservoir rocks.

\subsection{Sequence stratigraphic implications}

Two different interpretations have been proposed with regard to the sequence stratigraphy of the Furnas Formation (Fig. 1B). Excluding the uppermost storm-influenced transition beds, Bergamaschi (1999) considered the entire section of the Furnas Formation as a single transgressive-regressive cycle. In contrast, Assine (1996) placed a sequence boundary between the middle and upper units, based on the existence of lag pavements on ravinement surfaces between the middle and upper units, visible in outcrops and traceable in the subsurface using gammaray well logs.

Our data also suggest the existence of a significant stratigraphic discontinuity at the base of the upper unit (Fig. 7). During deposition of the lower and middle units (Lower Silurian according the ichnogenera reported here), sedimentation took place under relatively uniform conditions in tidally influenced regimes, and the finer sediment textures and greater ichnological diversity of the middle unit could be interpreted as an indication of transgression.

However, it is not yet possible to accurately determine the magnitude of the gap recognized between the middle and upper unit, owing to the lack of age-constraining fossils through the $100 \mathrm{~m}$-thick upper unit. Palynomorphs and primitive plant fossils have been recovered only near the top of the upper unit (maximum $30 \mathrm{~m}$ below the contact with the Ponta Grossa Formation) and these reveal lowest Devonian ages; i.e., Pragian (Dino and Rodrigues, 1995) or Lochkovian (Loboziak and Melo, 2002; Rubinstein et al., 2005; Milagres et al., 2007; Grahn et al., 2010).

The hiatus recognized between the middle and upper Furnas is coincident with the major sea-level fall that occurred during the Late Silurian (Ross and Ross, 1988; Johnson, 1996). However, it is not possible to affirm the time span between deposition of the lower and middle Furnas (Lower Silurian) and the upper Furnas (? Upper Silurian to Pragian) (Fig. 7).

There is no evidence of subaerial exposure in the studied sections, nor the existence of substrate-controlled ichnofacies. The presence of pavements of conglomerate lags is suggestive of sea level fall, fluvial progradation on shelfal environments and subsequent wave reworking and gravel concentration. This sedimentologic information is in accordance with ichnofacies changes, but the temporal significance of this disconformity within the Furnas Formation would not have been established without information provided by age-diagnostic ichnotaxa.

\section{Conclusions}

1. Seventeen ichnotaxa were identified in the Furnas Formation exposed in the Campos Gerais region of Brazil, doubling the number of ichnotaxa previously recognized in these strata. These traces record feeding, dwelling and/or locomotion activities of various invertebrate organisms (mainly arthropods, polychaetes, and mollusks). Associations of these ichnotaxa define two ichnofacies: Skolithos and proximal Cruziana ichnofacies.

2. In conjunction with evidence provided by suites of physical sedimentary features (e.g., sigmoidal stratification, mud drapes, and rare hummocky cross-stratification), ichnofossils indicate that Furnas deposition took place in a tide-dominated (locally storm-influenced), moderate- to high-energy, shallow marine environment.

3. Ichnotaxa with biostratigraphic significance (Arthrophycus alleghaniensis, A. brongniartii, Cruziana acacensis elongata) indicate an Early Silurian (Llandovery to Wenlock) age for the lower and middle units of the Furnas Formation.

4. Considering the Early Devonian (Lochkovian) age established for the upper unit by microfossil evidence, the contact between the middle and upper units of the Furnas Formation corresponds to a significant hiatus associated with the Late Silurian global sea-level

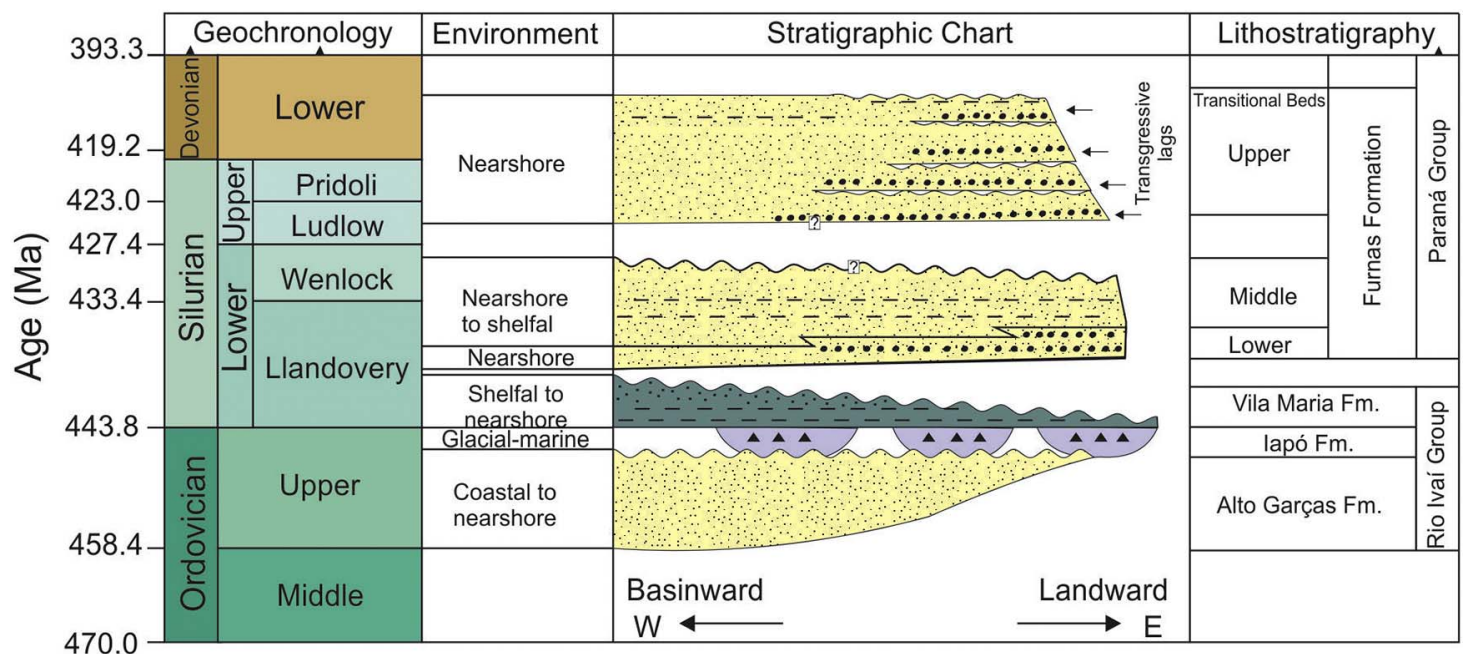

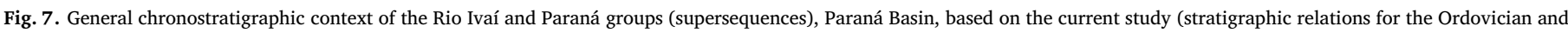
Devonian are based on Assine et al., 1994, 1998b; Milani et al., 2007; Grahn et al., 2010, 2013; Adôrno et al., 2016; ages are from Cohen et al., 2013). 
fall, and may record the Late Silurian (Pridoli) global regression.

5. The recognition of a new Lower Silurian stratigraphic sequence in the Paraná Basin has important implications for Gondwanan palaeogeography and economic resource potential.

\section{Acknowledgments}

DS thanks the Brazilian Coordination for the Improvement of Higher Education Personnel by PhD grant (CAPES/PROSUP) and research support (CSF-PVE-S Program 88887.129752/2016-00). Thanks to Brazilian National Council for Scientific and Technological Development for research support to RGN (CNPq grant 311473/20130 ) and to MLA (CNPq grants 308563/2013-1 and 459776/2014-2). Thanks also to FAPESP for financial support of MLA research (1998/ 02183-3). The authors are grateful to Adolf Seilacher for discussions in early fieldwork, to Andrew Rindsberg and an anonymous reviewer who helped improve the manuscript, and to the Paraná Environmental Institute (IAP) for allowing research in Guartelá State Park.

\section{Appendix A. Systematic ichnology}

Ichnogenus Didymaulyponomos Bradshaw, 1981

Didymaulyponomos rowei Bradshaw, 1981

Fig. 3D

2001 Furnasichnus langei Borghi and Fernandes, Figs.4, 5

Diagnosis: Horizontal, endichnial burrows with median ridge along the floor and with or without an infill (Bradshaw, 1981).

Material: Observations in situ (São Jorge-Alagados section; Guartelá section).

Description: These structures appear as horizontal, straight to sinuous, unbranched, and unornamented endichnial burrows with median furrows in their lower parts. Fills are structureless and similar or locally finer than surrounding sediment. Specimens are generally equidimensional with respect to width and height $(15-20 \mathrm{~mm})$ and may exceed $1 \mathrm{~m}$ in length.

Remarks: Recently, Buatois et al. (2017) suggested that Furnasichnus is a junior synonym of Didymaulichnus, arguing that Borghi and Fernandes (2001) established this new ichnogenus based on the assumption that Didymaulichnus is epigenic, while Furnasichnus is the product of endogenic activity. In his original description, Young (1972) did regard Didymaulichnus as an epigenetic trail. Hence, Didymaulichnus does differ from Furnasichnus in this regard. However, comparing the original diagnoses of Didymaulyponomos Bradshaw, 1981 and Furnasichnus Borghi and Fernandes, 2001 (horizontal, straight to sinuous, tubular, unornamented, unbranched burrows, with a median furrow in its lower part; fills with the same type of sediment of the host-rock), it is clear that they describe the same morphology. The only difference is that Borghi and Fernandes (2001) observed fill similar to the host sediment, while Bradshaw (1981) described fill finer than the host sediment. However, this textural difference does not justify ichnotaxonomic separation. Hence, we regard Furnasichnus as a junior synonym of Didymaulyponomos, a monospecific ichnogenus (D. rowei).

Bradshaw (1981) argued that Didymaulyponomos represents feeding or dwelling activity by arthropods below the sediment surface. Trewin and MacNamara (1994) observed that the "trail" Didymaulichnus is quite similar to the bottom surface of the burrow Didymaulyponomos, interpreting that an erosional event may be involved in Didymaulichnus preservation. Despite these similarities, both ichnogenera remain valid because it was not proved that they correspond to the same structure. Buatois et al. (2017) included this trace in their architectural design category "passively filled horizontal burrows", similar to Palaeophycus. The occurrences of $D$. rowei in the Furnas Formation are associated with Palaeophycus.

Ichnogenus Rusophycus Hall, 1852

Rusophycus acacensis $\mathrm{n}$. ichnosp.

Fig. 2F, G, J
Diagnosis: Bilobed, ovate, symmetrical traces with furrow exhibiting a distinct medial ridge on the lower surface and sets of five scratches.

Material: Observations in situ (São Jorge-Alagados section; Guartelá section). Holotype: ULVG-12261a (Fig. 2F); paratypes: ULVG-12261b and ULVG-12261.

Description: Short, bilobate burrows with medial ridges, having sets of five heavy and blunt scratch traces. The burrows range from 18 to $32 \mathrm{~mm}$ wide and 25 to $60 \mathrm{~mm}$ long. These bilobed traces are preserved in concave epirelief, normally with $3 \mathrm{~mm}$ depth. Locally, Rusophycus acacensis occurs connected with Cruziana acacensis elongata (compound trace fossils) (Fig. 2F-G).

Remarks: The name for this ichnospecies comes from the long trace fossil that is preserved connected to Cruziana acacensis. Although Seilacher (2007) did not propose Rusophycus acacensis as an ichnospecies, he noted that Cruziana acacensis elongata frequently is connected with a rusophyciform burrow. Netto et al. (2014) referred to these traces as Rusophycus cf. acacensis, considering their compound nature, and here we define this new ichnospecies.

The tracemakers of both Cruziana and Rusophycus are bilaterally symmetrical organisms, most probably arthropods (Donovan, 2010). In Paleozoic strata, they occur exclusively in marine deposits and are generally attributed to trilobites (Goldring, 1985; Fortey and Seilacher, 1997). In the current study, both $C$. acacensis and R. acacensis were produced by the same tracemaker in response to different behaviors.

\section{References}

Abdel-Fattah, Z.A., Gingras, M.K., Caldwell, M.W., Pemberton, S.J., MacEachern, J.A., 2016. The Glossifungites Ichnofacies and sequence stratigraphic analysis: a case study from middle to upper Eocene successions in Fayum, Egypt. Ichnos 23, 157-179. http://dx.doi.org/10.1080/10420940.2016.1185010.

Adôrno, R.R., Carmo, D.A., Salas, M.J., Zabini, C., Assine, M.L., 2016. The earliest Ostracoda record from Brazil: Vila Maria Formation, Rio Ivaí Group, Paraná Basin, central Brazil. Rev. Brasil. Paleontol. 19, 379-388. http://dx.doi.org/10.4072/rbp. 2016.3.03.

Almeida, F.F.M., 1954. Geologia do centro-leste Matogrossense. Bol. Divisão Geol. Mineral. DNPM 150, 1-97.

Assine, M.L., 1996. Aspectos da estratigrafia das sequências pré-carboníferas da Bacia do Paraná no Brasil (unpublished PhD. Thesis). São Paulo University, São Paulo (207 p).

Assine, M.L., 1999. Fácies, icnofósseis, paleocorrentes e sistemas deposicionais da Formação Furnas no flanco sudeste da Bacia do Paraná. Rev. Brasil. Geociênc. 29, 357-370.

Assine, M.L., Soares, P.C., Milani, E.J., 1994. Sequências tectono-sedimentares mesopaleozóicas da Bacia do Paraná, Sul do Brasil. Rev. Brasil. Geociênc. 24, 77-89.

Assine, M.L., Perinotto, J.A.J., Alvarenga, C.J.S., 1998a. Formação Iapó: glaciação continental no limite Ordoviciano/Siluriano da Bacia do Paraná. Rev. Brasil. Geociênc. 28, 51-60.

Assine, M.L., Perinotto, J.A.J., Alvarenga, C.J.S., Petri, S., 1998b. Arquitetura estratigráfica, tratos deposicionais e paleogeografia da Bacia do Paraná (Brasil) no Neo-Ordoviciano/Eo-Siluriano. Rev. Brasil. Geociênc. 28, 61-76.

Assine, M.L., Perinotto, J.A.J., Fulfaro, V.J., Petri, S., 1998c. Progradação deltaica Tibagi no Devoniano Médio da Bacia do Paraná. Rev. Brasil. Geociênc. 28, 125-134.

Baldwin, C.T., Strother, P.K., 2004. The internal structure and kinematics of production of the Paleozoic trace fossil Arthrophycus alleghaniensis and a possible non-trilobite tracemaker. In: First International Congress on Ichnology, Abstract Book Ichnia 2004, Trelew, pp. 17.

Bergamaschi, S., 1999. Análise estratigráfica do Siluro-Devoniano (Formações Furnas e Ponta Grossa) da sub-Bacia do Apucarana, Bacia do Paraná, Brasil (unpublished PhD. Thesis). São Paulo University, São Paulo (167 p).

Bigarella, J.J., 1973. Paleocorrentes e deriva continental (comparações entre a América do Sul e África). Bol. Paranaen. Geociênc. 31, 141-224.

Bigarella, J.J., Salamuni, R., 1967. Some paleogeographic features of the Brazilian Devonian. In: Bigarella, J.J. (Ed.), Problems in Brazilian Devonian Geology: Boletim Paranaense de Geografia. 21/22. pp. 133-151.

Bigarella, J.J., Salamuni, R., Marques Filho, L.P., 1966. Texturas e estruturas da Formação Furnas e sua significação paleogeográfica. Bol. Univ. Fed. Paraná 18, 1-114.

Borghi, L.F., 1993. Caracterização e análise faciológicas da Formação Furnas em afloramentos do bordo leste da Bacia do Paraná (unpublished M.S. Thesis). Rio de Janeiro University (227 p).

Borghi, L.F., Fernandes, A.C.S., 2001. A new trace fossil from the Devonian of the Paraná State (Paraná Basin), Brazil. Bol. Mus. Nac. 58, 1-12.

Borghi, L.F., Moreira, I.C., Fernandes, A.C.S., 1996. A ocorrência do icnogênero Arthrophycus Hall, 1852 em Chapada dos Guimarães, Estado de Mato Grosso. An. Acad. Bras. Cienc. 68, 274-275.

Bosetti, E.P., Grahn, Y., Horodyski, R.S., Mauller, P.M., Breuer, P., Zabini, C., 2011. An earliest Givetian "Lilliput Effect" in the Paraná Basin, and the collapse of the Malvinokaffric shelly fauna. Paläontol. Z. 85, 49-65. 
Bosetti, E.P., Horodyski, R.S., Matsumura, W.M.K., Myszynski-Junior, L.J., Sedorko, D., 2013. Análise estratigráfica e tafonômica da sequência Neopragiana-Eoemsiana do setor nordeste do sítio urbano de Ponta Grossa, Paraná, Brasil. Terra Plural 7 ,

145-168. http://dx.doi.org/10.5212/TerraPlural.v.7iEspecial.0010.

Bottjer, D.J., Droser, M.L., Jablonski, D., 1988. Palaeoenvironmental trends in the history of trace fossils. Nature 333, 252-255.

Bradshaw, M.A., 1981. Paleoenvironmental interpretations and systematics of Devonian trace fossils from the Taylor Group (lower Beacon Supergroup), Antarctica. N. Z. J. Geol. Geophys. 24, 615-652.

Brandt, D., Seitz, M., McCoy, V., Csonka, J., Barringer, J., Holmquist, E., Kraig, S., Morgan, R., Myers, J., Paquette, L., 2010. A new ichnospecies of Arthrophycus from the Late Carboniferous (Pennsylvanian) of Michigan, U.S.A. Ichnos 17, 12-19.

Brandt, D., Csonka, J., Holycross, M., McCoy, V., Seitz, M., 2012. In search of the Arthrophycus parallelus tracemaker. Palaios 27, 116-121. http://dx.doi.org/10.2110/ palo.2011.p11-101r.

Brett, C.E., 1998. Sequence stratigraphy, paleoecology, and evolution - biotic clues and responses to sea-level fluctuations. Palaios 13, 241-262.

Bromley, R.G., 1996. Trace Fossils - Biology, Taphonomy and Applications. Chapman and Hall, London (361 p).

Bromley, R.G., Asgaard, U., 1979. Triassic freshwater ichnocoenoses from Carlsberg Fjord, East Greenland. Palaeogeogr. Palaeoclimatol. Palaeoecol. 28, 39-80.

Buatois, L.A., Encinas, A., 2006. La icnofacies de Glossifungites en el contacto entre las formaciones Navidad (Miembro Rapel) y La Cueva, Plioceno de la Cordillera de la Costa, Chile: su significado estratigráfico-secuencial. Ameghiniana 43, 3-9.

Buatois, L.A., Mángano, M.G., 2011. Ichnology: Organism-Substrate Interactions in Space and Time. Cambridge University Press (358 p).

Buatois, L.A., Mángano, M.G., Genise, J.F., Taylor, T.N., 1998. The ichnologic record of the continental invertebrate invasion: evolutionary trends in environmental expansion, ecospace utilization, and behavioral complexity. Palaios 13, 217-240.

Buatois, L.A., Mángano, M.G., Aceñolaza, F.G., 2002. Trazas fósiles: Señales de comportamiento em el registro estratigráfico: Chubut, Museo Paleontológico Egidio Feruglio. (382 p).

Buatois, L.A., Wisshak, M., Wilson, M.A., Mángano, M.G., 2017. Categories of architectural designs in trace fossils: a measure of ichnodisparity. Earth Sci. Rev. 164, 102-181. http://dx.doi.org/10.1016/j.earscirev.2016.08.009.

Burjack, M.I.A., Popp, M.T.B., 1981. A ocorrência do icnogênero Arthrophycus no Paleozoico da Bacia do Paraná. Pesquisas 14, 163-168.

Clarke, J.M., 1913. Fósseis devonianos do Brasil: Serviço Geológico e Mineralógico do Brasil. (353 p).

Cohen, K.M., Finney, S.C., Gibbard, P.L., Fan, J.-X., 2013. The ICS International Chronostratigraphic Chart. Episodes 36, 199-204.

Coimbra, A.M., Riccomini, C., Boggiani, P.C., Gesicki, A.L.D., 1995. Paleocorrentes do sistema fluvial entrelaçado da Formação Furnas em Mato Grosso do Sul e suas implicações paleotectônicas. An. Acad. Bras. Cienc. 67, 520-520.

Crimes, T.P., 1969. Trace fossils from the Cambro-Ordovician rocks of North Wales and their stratigraphic significance. Geol. J. 6, 333-337.

Crimes, T.P., 1970. Trilobite tracks and other trace fossils from the Upper Cambrian of North Wales. Geol. J. 7, 47-68.

Crimes, T.P., 1975. Trilobite traces from the lower Tremadoc of Tortworth. Geol. Mag. 112, 33-46.

Dalrymple, R.W., Choi, K., 2007. Morphologic and facies trends through the fluvialmarine transition in tide-dominated depositional systems: a schematic framework for environmental and sequence-stratigraphic interpretation. Earth Sci. Rev. 81, 135-174.

Dino, R., Rodrigues, M.A.C., 1995. Palinomorfos eodevonianos da Formação Furnas, Bacia do Paraná. An. Acad. Bras. Cienc. 67, 107-116.

Donovan, S.K., 2010. Cruziana and Rusophycus: trace fossils produced by trilobites... in some cases? Lethaia 43, 283-284.

Ekdale, A.A., Lewis, D.W., 1991. Trace fossils and paleoenvironmental control of ichnofacies in a Late Quaternary gravel and loess fan delta complex, New Zealand. Palaeogeogr. Palaeoclimatol. Palaeoecol. 81, 253-279.

Faria, A., 1982. Formação Vila Maria - nova unidade litoestratigráfica siluriana da Bacia do Paraná. Ciências Terra 3, 12-15.

Fernandes, A.C.S., 1996. Os icnofósseis do Ordoviciano, Siluriano e Devoniano da Bacia do Paraná (Unpublished PhD Thesis). Graduate Program in Geosciences, Federal University of Rio de Janeiro, Rio de Janeiro (183 p).

Fernandes, A.C.S., Borghi, L.F., Moreira, M.I.C., 2000. Sobre a ocorrência do icnogênero Arthrophycus Hall, 1852 na Formação Furnas (Bacia do Paraná). Bol. Mus. Nac. 52, $1-14$.

Fielding, C.R., Bann, K.L., MacEachern, J.A., Tye, S.C., Jones, B.G., 2006. Cyclicity in the nearshore marine to coastal, Lower Permian, Pebbley Beach Formation, southern Sydney Basin, Australia: a record of relative sea-level fluctuations at the close of the late Palaeozoic Gondwanan ice age. Sedimentology 53, 435-463.

Fillion, D., Pickerill, R.K., 1990. Ichnology of the Upper Cambrian? to Lower Ordovician Bell Island and Wabana groups of eastern Newfoundland, Canada. Palaeontogr. Can. 7, 1-119.

Fortey, R.A., Seilacher, A., 1997. The trace fossil Cruziana semiplicata and the trilobite that made it. Lethaia 30, 105-112.

Frey, R.W., 1990. Trace fossils and hummocky cross-stratification, Upper Cretaceous of Utah. Palaios 5, 203-218.

Frey, R.W., Howard, J.D., 1985. Trace fossils from the Panther Member, Star Point Formation (Upper Cretaceous), Coal Creek Canyon, Utah. J. Paleontol. 59, 370-404.

Frey, R.W., Howard, J.D., 1990. Trace fossils and depositional sequences in a clastic shelf setting, Upper Cretaceous of Utah. J. Paleontol. 64, 803-820.

Gerrienne, P., Bergamaschi, S., Pereira, E., Rodrigues, M.A.C., Steemans, P., 2001. An Early Devonian flora, including Cooksonia from the Paraná Basin (Brazil). Rev.
Palaeobot. Palynol. 116, 19-38.

Glaessner, M.F., 1969. Trace fossils from the Precambrian and basal Cambrian. Lethaia 2 , 369-393.

Goldring, R., 1985. The formation of the trace fossil. Cruziana Geol. Mag. 122, 65-72

Goldring, R., Pollard, J.E., Radley, J.D., 2005. Trace fossils and pseudofossils from the Wealden strata (non-marine Lower Cretaceous) of southern England. Cretac. Res. 26, $665-685$.

Grahn, C.Y., 1992. Revision of Silurian and Devonian strata of Brazil. Palynology 16, $35-61$.

Grahn, C.Y., Mendlowics-Mauller, P., Breuer, P., Bosetti, E.P., Bergamaschi, S., Pereira, E. 2010. The Furnas/Ponta Grossa contact and the age of the lowermost Ponta Grossa Formation in the Apucarana sub-Basin (Paraná Basin, Brazil): integrated palynological age determination. Rev. Brasil. Paleontol. 13, 89-102.

Grahn, C.Y., Mendlowicz-Mauller, P., Bergamaschi, S., Bosetti, E.P., 2013. Palynology and sequence stratigraphy of three Devonian rock units in the Apucarana Subbasin (Paraná Basin, south Brazil): additional data and correlation. Rev. Palaeobot. Palynol. 198, 27-44.

Gray, J., Colbath, G.K., Faria, A., Boucot, A.J., Rohr, D.M., 1985. Silurian-age fossils from Paleozoic Paraná Basin, southern Brazil. Geology 13, 521-525.

Hakes, W.G., 1976. Trace fossils and depositional environment of four clastic units, Upper Pennsylvanian megacyclothems, northeast Kansas. Univ. Kansas Paleontol. Contrib. 63, 1-46.

Herringshaw, L.G., Sherwood, O.A., McIlroy, D., 2010. Ecosystem engineering by bioturbating polychaetes in event bed microcosms. Palaios 25, 46-58.

Horodyski, R.S., Holz, M., Bosetti, E.P., 2014. Remarks on the sequence stratigraphy and taphonomy of the relictual Malvinokaffric fauna during the Kačák event in the Paraná Basin, Brazil. Int. J. Earth Sci. 103, 367-380. http://dx.doi.org/10.1007/s00531013-0954-9.

Johnson, M.E., 1996. Stable cratonic sequences and a standard for Silurian eustasy. In: Witzke, B.J., Ludvigson, G.A., Day, J.E. (Eds.), Paleozoic Sequence Stratigraphy: Views From the North American Craton. Geological Society of America, Specia Paper. 306. pp. 203-211.

Knaust, D., 2013. The ichnogenus Rhizocorallium: classification, trace makers, palaeoenvironments and evolution. Earth Sci. Rev. 126, 1-47.

Lange, F.W., Petri, S., 1967. The Devonian of the Paraná basin. Bol. Paranaen. Geociênc. 21/22, 5-55.

Leszczyński, S., Uchman, A., Bromley, R.G., 1996. Trace fossils indicating bottom aeration changes: Folusz Limestone, Oligocene, Outer Carpathians, Poland. Palaeogeogr. Palaeoclimatol. Palaeoecol. 121, 79-87.

Loboziak, S., Melo, J.H.G., 2002. Devonian miospore successions of Western Gondwana: update and correlation with South Euramerican miospore zones. Rev. Palaeobot. Palynol. 121, 133-148.

Maack, R., 1946. Geologia e geografia da região de Vila Velha e considerações sobre a glaciação carbonífera do Brasil. Arq. Mus. Paranaen. 5 (305 p).

Maack, R., 1947. Breves notícias sobre a geologia dos estados do Paraná e Santa Catarina. Curitiba. Arq. Biol. Tecnol. 2, 63-154.

MacEachern, J.A., Raychaudhuri, I., Pemberton, S.G., 1992. Stratigraphic applications of the Glossifungites Ichnofacies-delineating discontinuities in the rock record. In: Pemberton, S.G. (Ed.), Applications of Ichnology to Petroleum Exploration-A Core Workshop. 17. Society of Economic Paleontologists and Mineralogists, Core Workshop, pp. 169-198.

MacEachern, J.A., Stelck, C.R., Pemberton, S.G., 1999. Marine and marginal marine mudstone deposition: paleoenvironmental interpretations based on the integration of ichnology, palynology and foraminiferal paleoecology. In: Bergaman, K.M., Snedden, J.W. (Eds.), Isolated Shallow Marine Sand Bodies: Sequence Stratigraphic Analysis and Sedimentological Interpretation: Society for Sedimentary Geology Special Publication. 64. pp. 205-225.

Mángano, M.G., Buatois, L.A., 2003. Rusophycus leiferikssoni Bergström en la Formación Campanario: implicancias en la paleoecología de planicies mareales cámbricas. 9. Asociación Paleontológica Argentina, pp. 65-84.

Mángano, M.G., Droser, M., 2004. The ichnologic record of the Ordovician radiation. In: Webby, B.D., Droser, M.L., Paris, F., Percival, I.G. (Eds.), The Great Ordovician Biodiversification Event. Columbia University Press, New York, pp. 369-379.

Mángano, M.G., Buatois, L.A., West, R.R., Maples, C.G., 1998. Contrasting behavioral and feeding strategies recorded by tidal-flat bivalve trace fossils from the Upper Carboniferous of eastern Kansas. Palaios 13, 335-351.

Mángano, M.G., Buatois, L.A., Moya, M.C., 2001. Trazas fósiles de trilobites de la Formación Mojotoro (Ordovícico inferior-medio de Salta, Argentina): implicancias paleoecológicas, paleobiológicas y bioestratigráficas. Rev. Esp. Paleont. 16, 9-28.

Mángano, M.G., Buatois, L.A., Rindsberg, A.K., 2003. Carboniferous Psammichnites: systematic re-evaluation, taphonomy and autecology. Ichnos 9, 1-22.

Mángano, M.G., Carmona, N.B., Buatois, L.A., Muñiz-Guinea, F., 2005. A new ichnospecies of Arthrophycus from the Upper Cambrian - lower Tremadocian of northwest Argentina: implications for the arthrophycid lineage and potential in ichnostratigraphy. Ichnos 12, 179-190.

Matsumura, W.M.K., Iannuzzi, R., Bosetti, E.P., 2015. Middle Devonian herbaceous lycopsid Haplostigma from the Paraná Basin, Brazil: taxonomy, biostratigraphy and phytogeography. Geobios 48, 397-415.

McCoy, V.E., Strother, P.K., Briggs, D.E.G., 2012. A possible tracemaker for Arthrophycus alleghaniensis. J. Paleontol. 86, 996-1001.

Melo, J.H.G., 1988. The Malvinokaffric Realm in the Devonian of Brazil. In: McMillan, N.J., Embry, A.F., Glass, D.J. (Eds.), Devonian of the World: Proceedings of the Second International Symposium on the Devonian System, Calgary: Canada, pp. 669-976.

Milagres, I.M., Pereira, E., Bergamaschi, S., Rodrigues, M.A.C., Gerrienne, P., 2007. O registro da tafoflora devoniana observada no arco de Ponta Grossa, bacia do Paraná, e 
suas implicações paleogeográficas. In: Carvalho, I.S., Tardín, R.C. (Eds.) Paleontologia, Cenários de Vida: Editora Interciência. 1. pp. 25-48.

Milani, E.J., Melo, J.H.G., Souza, P.A., Fernandes, L.A., França, A.B., 2007. Bacia do Paraná. Bol. Geociênc. Petrobrás 15, 265-287.

Minter, N.J., Buatois, L.A., Mángano, M.G., MacNaughton, R.B., Davies, N.S., Gibling, M.R., 2016. The prelude to continental invasion. In: Mángano, M.G., Buatois, L.A. (Eds.), The Trace-Fossil Record of Major Evolutionary Events - Precambrian and Paleozoic. 1. Springer, pp. 157-204. http://dx.doi.org/10.1007/978-94-017-9600-2.

Mude, S.N., Jagtap, S.A., Kundal, P., Sarkar, P.K., Kundal, M.P., 2012. Paleoenvironmental significance of ichnofossils from the Mesozoic Jaisalmer Basin, Rajasthan, north western India. In: Proceedings of the International Academy of Ecology and Environmental Sciences. 2. pp. 150-167.

Mussa, D., Borghi, L., Bergamaschi, S., Schubert, G., Pereira, E., Rodrigues, M.A.C., 1996. Estudo preliminar da tafoflora da Formação Furnas, bacia do Paraná, Brasil. An. Acad. Brasil. Ciências 68, 65-89.

Myrow, P.M., 1995. Thalassinoides and the enigma of early Paleozoic open-framework burrow systems. Palaios 10, 58-74.

Nara, M., 1995. Rosselia socialis: a dwelling structure of a probable terebellid polychaete. Lethaia 28, 171-178. http://dx.doi.org/10.1111/j.1502-3931.1995.tb01610.x.

Neto de Carvalho, C., Fernandes, A.C.S., Borghi, L.F., 2002. Diferenciação das icnoespécies e variantes de Arthrophycus e sua utilização problemática em icnoestratigrafia: homoplasias comportamentais de anelídeos e artrópodes? Rev. Esp. Paleont. 18, 221-228.

Netto, R.G., Balistieri, P.R.M.N., Lavina, E.L.C., Silveira, D.M., 2009. Ichnological signatures of shallow freshwater lakes in the glacial Itararé Group (Mafra Formation, Upper Carboniferous Lower Permian of Paraná Basin, S Brazil). Palaeogeogr. Palaeoclimatol. Palaeoecol. 272, 240-255.

Netto, R.G., Tognoli, F.M.W., Gandini, R., Lima, J.H.D., Gibert, J.M., 2012. Ichnology of the Phanerozoic deposits of southern Brazil: synthetic review. In: Netto, R.G., Carmona, N.B., Tognoli, F.M.W. (Eds.), Ichnology of Latin America - Selected Papers: Monografias da Sociedade Brasileira de Paleontologia. 2. pp. 37-68.

Netto, R.G., Tognoli, F.M.W., Assine, M.L., Nara, M., 2014. Crowded Rosselia ichnofabric in the Early Devonian of Brazil: an example of strategic behavior. Palaeogeogr. Palaeoclimatol. Palaeoecol. 395, 107-113. http://dx.doi.org/10.1016/j.palaeo.2013. 12.032.

Northfleet, A.A., Medeiros, R.A., Mülhmann, H., 1969. Reavaliação dos dados geológicos da Bacia do Paraná. Bol. Técnico Petrobrás 12, 291-346.

Osgood, R.G., 1970. Trace fossils of the Cincinnati area. Palaeontogr. Am. 6, 281-444.

Paranjape, A.R., Kulkarni, K.G., Kale, A.S., 2014. Sea level changes in the upper Aptianlower/middle(?) Turonian sequence of Cauvery Basin, India - an ichnological perspective. Cretac. Res. 56, 1-14.

Pemberton, S.G., Frey, R.W., 1982. Trace fossil nomenclature and the Planolites-Palaeophycus dilemma. J. Paleontol. 56, 843-881.

Pemberton, S.G., Frey, R.W., 1984. Ichnology of storm-influenced shallow marine sequence: Cardium Formation (Upper Cretaceous) at Seebe, Alberta. In: Stoott, D.F., Glass, D.J. (Eds.), The Mesozoic of Middle North America: Canadian Society of Petroleum Geologists, Memoir. 9. pp. 281-304.

Pemberton, S.G., Jones, B., 1988. Ichnology of the Pleistocene Ironshore Formation, Grand Cayman Island, British West Indies. J. Paleontol. 62, 495-505.

Pemberton, S.G., MacEachern, J.A., Gingras, M.K., Zhang, J., 2000. Significance of ichnofossils to genetic stratigraphy - examples from the Cretaceous of Alberta, Canada. Sci. China 43, 541-560.

Pereira, E., Bergamaschi, S., 1996. Estudo da evolução tectono-sedimentar das seqüências ordoviciana, siluriana e devoniana nas sub-bacias Apucarana e Alto Garças, Bacia do Paraná, Gondwana Ocidental. In: Simpósio Sul-Brasileiro do Siluro-Devoniano, 1996, Ponta Grossa, pp. 219-238.

Pereira, E., Bergamaschi, S., Rodrigues, M.A.C., 1998. Sedimentary evolution of the Ordovician, Silurian and Devonian sequences of Paraná Basin in Brazil. Zbl. Geol. Paläontol. 3, 779-792.

Petri, S., 1948. Contribuição ao estudo do Devoniano paranaense: Departamento Nacional da Produção Mineral. (125 p).

Petri, S., Fúlfaro, J.V., 1983. Geologia do Brasil. In: Queiroz, T.A. (Ed.), USP, (631 p).

Plotnick, R.E., 2012. Behavioral biology of trace fossils. Paleobiology 38, 459-473.

Popp, J.H., Barcellos-Popp, M., 1986. Análise estratigráfica da sequiência devoniana da bacia do Paraná (Brasil). Rev. Brasil. Geociênc. 16, 187-194.

Popp, M.T.B., Burjack, M.I., Esteves, L.R., 1981. Estudo preliminar sobre o conteúdo paleontológico da Formação Vila Maria (pré-Devoniano) da Bacia do Paraná. Pesquisas 14, 169-180.

Reading, H.G., 1996. Sedimentary Environments: Processes, Facies and Stratigraphy. Blackwell, Oxford (689 p).

Reineck, H.-E., 1963. Sedimentgefüge im Bereich der südlichen Nordsee. Abh. Senckenb. Naturforsch. Ges. 505, 1-138.

Rindsberg, A., 1994. Ichnology of the Upper Mississippian Hartselle sandstone of Alabama, with notes on other Carboniferous formations. Geol. Sur. Alabama, Bull. $158,107$.

Rindsberg, A.K., 2012. Ichnotaxonomy: finding patterns in a welter of information. In: Knaust, D., Bromley, R.G. (Eds.), Trace Fossils as Indicators of Sedimentary Environments. Elsevier, Developments in Sedimentology 64. pp. 43-78.

Rindsberg, A.K., Martin, A.J., 2003. Arthrophycus in the Silurian of Alabama (USA) and the problem of compound trace fossils. Palaeogeogr. Palaeoclimatol. Palaeoecol. 192,
$187-219$.

Rodrigues, M.A.C., Pereira, E., Bergamaschi, S., 1989. Ocorrência de Psilophytales na Formação Furnas, borda leste da Bacia do Paraná: Boletim do IG-USP. 7. pp. 35-43.

Rodrigues, S.C., Simões, M.G., Leme, J.M., 2003. Tafonomia comparada dos Conulatae (Cnidaria), Formação Ponta Grossa (Devoniano), Bacia do Paraná, Estado do Paraná. Rev. Brasil. Geociênc. 33, 381-390.

Rodríguez-Tovar, F.J., Pérez-Valera, F., Pérez-López, A., 2006. Ichnological analysis in high-resolution sequence stratigraphy: the Glossifungites ichnofacies in Triassic successions from the Betic Cordillera (southern Spain). Sediment. Geol. 198, 293-307.

Rodríguez-Tovar, F.J., Uchman, A., Payros, A., Orue-Etxebarria, X., Apellaniz, E., Molina, E., 2010. Sea-level dynamics and palaeoecological factors affecting trace fossil distribution in Eocene turbiditic deposits (Gorrondatxe section, N Spain). Palaeogeogr. Palaeoclimatol. Palaeoecol. 285, 50-65.

Ross, C.A., Ross, J.R.P., 1988. Late Paleozoic transgressive-regressive deposition. In: Wilgus, C.K., Hastings, B.S., Kendall, C.G.S.C., Posamentier, H.M., Ross, C.A., Van Wagoner, J.C. (Eds.), Sea-Level Changes - An Integrated Approach: Society of Economic Paleontologists and Mineralogists, Special Publication. 42. pp. 227-247.

Rubinstein, C., Melo, J.H.G., Steemans, P., 2005. Lochkovian (earliest Devonian) miospores from the Solimões Basin, northwestern Brazil. Rev. Palaeobot. Palynol. 133, 91-113.

Sanford, R.M., Lange, F.W., 1960. Basin study approach to oil evaluation of Paraná miogeosyncline, south Brazil. Bull. Am. Assoc. Pet. Geol. 44, 1316-1370.

Savrda, C.E., 1991a. Ichnology in sequence stratigraphic studies: an example from the lower Paleocene of Alabama. Palaios 6, 39-53.

Savrda, C.E., 1991b. Teredolites, wood substrates, and sea-level dynamics. Geology 19, 905-908.

Savrda, C.E., 1995. Ichnologic applications in paleoceanographic, paleoclimatic, and sealevel studies. Palaios 10, 565-577.

Savrda, C.E., Bottjer, D.J., 1986. Trace fossil model for reconstruction of paleooxygenation in bottom water. Geology 14, 3-6.

Savrda, C.E., Nanson, L.L., 2003. Ichnology of fair-weather and storm deposits in an Upper Cretaceous estuary (Eutaw Formation, western Georgia, USA). Palaeogeogr. Palaeoclimatol. Palaeoecol. 202, 67-83.

Schneider, R.L., Muhlmann, H., Tommasi, E., Medeiros, R.A., Daemon, R.F., Nogueira A.A., 1974. Revisão estratigráfica da Bacia do Paraná. In: Congresso Brasileiro de Geologia, 28, Porto Alegre: Sociedade Brasileira de Geologia, pp. 41-65.

Sedorko, D., Bosetti, E.P., Netto, R.G., 2017. An integrative ichnologic and taphonomic approach in a transgressive-regressive cycle: a case study from Devonian of Paraná Basin, Brazil. Lethaia. http://dx.doi.org/10.1111/let.12219. (in press).

Seilacher, A., 1967. Bathymetry of trace fossils. Mar. Geol. 5, 413-428.

Seilacher, A., 1970. Cruziana stratigraphy of "nonfossiliferous" Palaeozoic sandstones. In: Crimes, T.P., Harper, J.C. (Eds.), Trace Fossils. Geological Journal 3. pp. 447-476.

Seilacher, A., 1992. In: Salem, M.J., Hammuda, O.S., Eliagoubi, B.A. (Eds.), An updated Cruziana stratigraphy of Gondwanan Palaeozoic sandstones. The Geology of Libya, Elsevier, Amsterdam, pp. 1565-1580.

Seilacher, A., 1994. How valid is Cruziana stratigraphy? Geol. Rundsch. 83, 752-758.

Seilacher, A., 1996. Evolution of burrowing behaviour in Silurian trilobites: ichnosubspecies of Cruziana acacensis. In: Salem, M.J., Mzoughi, A.J., Hammuda, O.S. (Eds.), The Geology of the Sirt Basin. Elsevier, Amsterdam, pp. 523-530.

Seilacher, A., 1997. Fossil Art - An Exhibition of the Geologisches Institut Tübingen University: Royal Tyrell Museum of Palaeontology, Drumheller, Alberta, Canada. (64 p).

Seilacher, A., 2000. Ordovician and Silurian arthrophycid ichnostratigraphy. In: Sola, M.A., Worsley, D. (Eds.), Geological Exploration in Murzuk Basin. Elsevier, Amsterdam, pp. 237-258.

Seilacher, A., 2007. Trace Fossil Analysis. Springer, Berlin (226 p).

Seilacher, A., Seilacher, E., 1994. Bivalvian trace fossils: a lesson from actuopaleontology. Cour. Forschungsinst. Senck. 169, 5-15.

Seitz, M.E., 2010. A reconsideration of the Arthrophycus ichnogenus: definition, biostratigraphic utility, and a proposal to develop a numerical ichnotaxonomy (unpublished $\mathrm{PhD}$. thesis). Michigan State University (241 p).

Srivastava, A.K., Mankar, D., 2012. Dilemma of late Palaeozoic mixed floras in Gondwana. Palaeogeogr. Palaeoclimatol. Palaeoecol. 298, 54-69.

Trewin, N.H., MacNamara, K.J., 1994. Arthropods invade the land: trace fossils and palaeoenvironments of the Tumblagooda Sandstone (?Late Silurian) of Kalbarri, Western Australia. Trans. R. Soc. Edinb. 85, 177-210.

Turner, B.R., Stanistreet, I.G., Whateley, M.K.G., 1981. Trace fossils and palaeoenvironments in the Ecca Group of the Nongoma Graben, northern Zululand, South Africa. Palaeogeogr. Palaeoclimatol. Palaeoecol. 36, 113-123.

Vossler, S.M., Pemberton, S.G., 1989. Ichnology and paleoecology of offshore siliciclastic deposits in the Cardium formation (Turonian, Alberta, Canada). Palaeogeogr. Palaeoclimatol. Palaeoecol. 74, 217-239.

Young, F.G., 1972. Early Cambrian and older trace fossils from the Southern Cordillera of Canada. Can. J. Earth Sci. 9, 1-17.

Zalán, P.V., Wolff, S., Conceição, J.C.J., Vieira, I.S., Astolfi, M.A.M., Appi, V.T., Zanotto, O.A., 1987. A divisão tripartite do Siluriano da Bacia do Paraná. Rev. Brasil. Geociênc. 17, 242-252.

Zonneveld, J.-P., Pemberton, S.G., Saunders, T.D.A., Pickerill, R.K., 2002. Large, robust Cruziana from the Middle Triassic of northeastern British Columbia: ethologic, biostratigraphic, and paleobiologic significance. Palaios 17, 435-448. 